\title{
From the western boundary currents to the Pacific Equatorial Undercurrent: Modeled pathways and water mass evolutions
}

\author{
Mélanie Grenier, ${ }^{1}$ Sophie Cravatte, ${ }^{1,2}$ Bruno Blanke, ${ }^{3}$ Christophe Menkes, ${ }^{4,5}$ \\ Ariane Koch-Larrouy, ${ }^{1,2}$ Fabien Durand, ${ }^{1,6}$ Angélique Melet, ${ }^{7}$ and Catherine Jeandel ${ }^{1,8}$ \\ Received 29 July 2011; revised 21 October 2011; accepted 25 October 2011; published 30 December 2011.
}

[1] The hydrological and geochemical properties of the waters constituting the Pacific Equatorial Undercurrent (EUC) determine the properties of the equatorial cold tongue. Understanding and quantifying the various EUC origins is therefore of prime importance. For this purpose, a high-resolution $\left(1 / 4^{\circ}\right)$ interannual oceanic simulation was analyzed from the western tropical Pacific boundaries to $140^{\circ} \mathrm{W}$, using a Lagrangian framework. Waters from the Low-Latitude Western Boundary Currents (LLWBCs) transiting from Vitiaz Strait (the main contributor), from Solomon Strait, and via the Mindanao Current were identified as the principal sources to the EUC. Waters conveyed by the interior ocean off equator are negligible till $180^{\circ} \mathrm{E}$. The LLWBCs' waters represent $87 \%$ of the EUC transport at $156^{\circ} \mathrm{E}$ out of which the New Guinea Coastal Undercurrent (NGCU) is as large as $47 \%$. The EUC meridional distribution suggests that the waters originating from Solomon Strait and Mindanao Current mostly remain in the hemisphere from which they originate. Contrastingly, Vitiaz Strait waters are found in both hemispheres. The vertical EUC distribution shows that the lower layer of the EUC is mainly composed of Vitiaz Strait waters. Finally, the source transport distributions were characterized, at their origin and within the EUC, as a function of density. These distributions showed that waters flowing through Vitiaz Strait at densities higher than those of the EUC (down to $\sigma_{\theta}=27.2 \mathrm{~kg} \mathrm{~m}^{-3}$ ) undergo a diapycnal mixing and lighten during their journey to join the EUC. This lightening supports the suggestion that the NGCU is a major source for the EUC geochemical enrichment.

Citation: Grenier, M., S. Cravatte, B. Blanke, C. Menkes, A. Koch-Larrouy, F. Durand, A. Melet, and C. Jeandel (2011), From the western boundary currents to the Pacific Equatorial Undercurrent: Modeled pathways and water mass evolutions, J. Geophys. Res., 116, C12044, doi:10.1029/2011JC007477.

\section{Introduction}

[2] Along the equatorial Pacific, the Equatorial Undercurrent (EUC) flows eastward as a powerful narrow tongue, salty and oxygenated, from north of Papua New Guinea (PNG) to the coast of South America [e.g., Johnson et al., 2002]. The EUC is $500 \mathrm{~km}$ wide, centered on the $200 \mathrm{~m}$ depth in the western part of the basin, and then it gradually shoals along its $14,000 \mathrm{~km}$ pathway. It upwells in the eastern equatorial Pacific into the overlying South Equatorial

\footnotetext{
${ }^{1}$ LEGOS, Université de Toulouse, UPS, OMP-PCA, Toulouse, France. ${ }^{2}$ LEGOS, IRD, Toulouse, France.

${ }^{3}$ Laboratoire de Physique des Océans, UMR 6523, CNRS/IFREMER/ IRD/UBO, Université de Bretagne Occidentale, UFR Sciences, Brest, France.

${ }^{4}$ LOCEAN, UPMC/IRD/CNRS/MNHN, Université Pierre et Marie Curie, Paris, France.

${ }^{5}$ LOCEAN-IRD Nouméa, Nouméa, New Caledonia.

${ }^{6}$ LEGOS-IRD Nouméa, Nouméa, New Caledonia.

${ }^{7}$ LEGI, UMR 5519, CNRS, Université de Grenoble, Grenoble, France.

${ }^{8}$ LEGOS, CNRS, Toulouse, France.
}

Copyright 2011 by the American Geophysical Union. 0148-0227/11/2011JC007477
Current (SEC) and diverges from the equator. The EUC transports a variety of density horizons (approximately from 23 to $26.5 \mathrm{~kg} \mathrm{~m}^{-3}$ ) and other properties [Tsuchiya et al., 1989; Gouriou and Toole, 1993]. It is the main source of water masses upwelled in the equatorial cold tongue in the central eastern Pacific.

[3] In terms of biogeochemistry, the equatorial Pacific upwelling supports $\sim 20 \%$ of the world's primary production [Chavez and Barber, 1987; Chavez and Toggweiler, 1995], but it is also a high-nutrient, low-chlorophyll (HNLC) region, a characterization arising from the relatively low-chlorophyll content compared to what would be expected from the high concentration of macronutrients. The consensus is that the region is limited by micronutrients, among which iron seems to be the main limitation [Martin et al., 1994; Murray et al., 1994; Gordon et al., 1997; Landry et al., 1997]. Although the EUC is possibly the main micronutrient conveyor to the equatorial Pacific, data are still lacking to completely characterize its role on the iron fluxes supporting primary production in the equatorial upwelling [Gordon et al., 1997; Slemons et al., 2009, 2010].

[4] The transports of EUC water in the central eastern Pacific are known to be dependent on the EUC sources. 


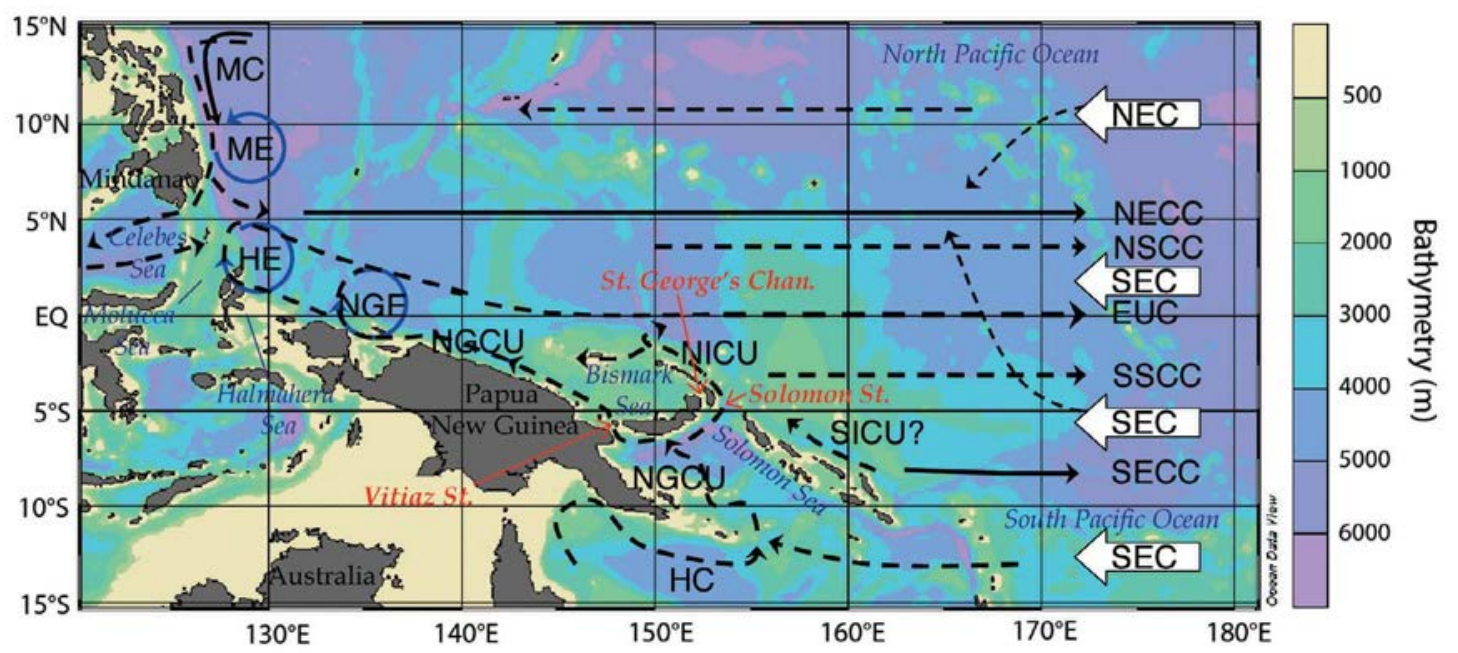

Figure 1. Schematic map of the major surface currents (solid arrows) and subsurface currents (dashed arrows) in the western tropical Pacific Ocean: westward North Equatorial Current (NEC) and South Equatorial Current (SEC); equatorward Mindanao Current (MC), New Guinea Coastal Undercurrent (NGCU), New Ireland Coastal Undercurrent (NICU), and Solomon Island Coastal Undercurrent (SICU); and eastward Hiri Current (HC), North and South Subsurface Countercurrents (NSCC and SSCC), North and South Equatorial Countercurrents (NECC and SECC), and Equatorial Undercurrent (EUC). The Mindanao Eddy (ME), the Halmahera Eddy (HE), and the New Guinea Eddy (NGE) are also shown. Vitiaz and Solomon Straits and the St. George's Channel are identified in red.

Improving our knowledge about the EUC sources and their hydrological and geochemical properties is important for two reasons. First, water masses conveyed by this current are primary constituents of the equatorial thermocline waters and are therefore suspected to play a crucial role in climate variations and in modulation of the ENSO (El Niño Southern Oscillation) cycle. Indeed, on the one hand, it has been suggested that the EUC is advecting spiciness anomalies (density-compensating temperature and salinity anomalies) formerly subducted in the subtropics. These anomalies may eventually contribute to the decadal changes observed in the structure of the equatorial pycnocline and partly explain the observed decadal variability of ENSO [e.g., Schneider, 2004]. On the other hand, variations of EUC transport may lead to variations of nutrient supplies to the photic layer [Ryan et al., 2006; Slemons et al., 2009; Gorgues et al., 2010], therefore modifying key elements of the food web such as the primary production of the HNLC area and involving climatic and economic (fisheries) consequences.

[5] The main pathways of the EUC water sources have been previously studied. As a summary, Figure 1 presents a schematic view of the circulation in the western tropical Pacific, building on Figure 1 from Fine et al. [1994] and Kashino et al. [2007] and Plate 2 from Schott et al. [2004]. EUC water sources are mainly subducted in the subtropics and advected by meridional convergence in the pycnocline following either an interior oceanic pathway [Johnson and McPhaden, 1999; Schott et al., 2004] or the Low-Latitude Western Boundary Currents (LLWBCs) [Tsuchiya et al. 1989; Fine et al., 1994]. The LLWBCs converge in the western equatorial Pacific, where the circulation is complicated (Figure 1). From the north, the Mindanao Current (MC) flows southward along the Philippine Islands [Wijffels et al., 1995; Kashino et al., 2007] and feeds the Indonesian
Throughflow, the North Equatorial Countercurrent (NECC) and the EUC [Fine et al., 1994]. From the south, a double boundary current system flows through and east of the Solomon Sea [Melet et al., 2010a; Cravatte et al., 2011]. The main branch, the New Guinea Coastal Undercurrent (NGCU), flows northwestward along PNG, exiting the Solomon Sea through Vitiaz Strait [Lindstrom et al., 1987; Tsuchiya et al., 1989; Ueki et al., 2003]. The second branch, the New Ireland Coastal Undercurrent (NICU) flows along the eastern coast of New Ireland [Butt and Lindstrom, 1994; Melet et al., 2010a]. It is fed by the current flowing through Solomon Strait, by the SEC and potentially by a western boundary current flowing along the Solomon Islands, the Solomon Island Coastal Undercurrent (SICU), described by Melet et al. [2010a]. These authors found that, climatologically, half of the NICU turns westward in the Bismarck Sea to join the NGCU, and half directly retroflects into the EUC. This retroflection would be the most direct route for subtropical thermocline water on its way to the equator via the western boundary.

[6] More quantitatively, several model studies [Blanke and Raynaud, 1997; Rodgers et al., 2003; Fukumori et al., 2004; Goodman et al., 2005] estimated that $2 / 3$ of the EUC sources are located in the southern Pacific and $1 / 3$ in the northern Pacific. Using climatological simulations, Blanke and Raynaud [1997] estimated that more than $60 \%$ of the southern supply flows along the southwestern boundaries. The global climate model used by Goodman et al. [2005] suggested that, seasonally, more than half of the Pacific EUC at $140^{\circ} \mathrm{W}$ originates south of the equator. These authors also concluded that LLWBCs were major contributors to the EUC flow, transporting $3 / 4$ of the EUC waters. In contrast, Izumo et al. [2002] found a more balanced contribution from both hemispheres, when modeling 
the sources of the EUC outcropping water during the rapid transition between El Niño and La Niña events, in May 1998.

[7] Several questions remain concerning the EUC sources. Most of the previous numerical studies defined the southern LLWBCs as a broad region west of $160^{\circ} \mathrm{E}$, without distinguishing the NGCU from the NICU. Differentiating these routes may be important for the EUC in several ways. First, the longitude at which waters join the EUC, as well as their transit time, may change depending on the sources with potential repercussions on the rapidity of the equatorial response to changes in the southwest Pacific circulation. Also, whether waters transit or not through the Solomon Sea is important for the definition of the equatorial water mass geochemical properties. Indeed, the PNG coast has been hypothesized to be the primary source of micronutrients for the deeper layers of the EUC [Mackey et al., 2002]. Lacan and Jeandel [2001] suggested that NGCU waters were enriched in lithogenic inputs by dissolution of continental material as they flowed along the PNG slope. This hypothesis was confirmed by Slemons et al. [2010, also Particulate iron, aluminium and manganese in the Pacific equatorial undercurrent and low latitude western boundary current sources, submitted to Marine Chemistry, 2011], who showed high concentrations of total dissolvable iron and particulate iron in the western equatorial Pacific, decreasing eastward but persisting to $140^{\circ} \mathrm{W}$ in the lower EUC. Hence, understanding the role and routes of the respective sources of the EUC waters is of crucial importance in understanding the concentrations of micro and macronutrients supporting primary production in the eastern Pacific.

[8] Surprisingly enough, little is known about (1) the distribution of these hydrographic sources within the EUC, (2) the evolution of this distribution from the western to the central equatorial Pacific, and (3) the densities of the sources feeding the EUC. While some hypotheses have been made on the basis of water mass hydrological properties [e.g., Tsuchiya et al., 1989], the lack of observational data over a long time range prevents precise determination of the above mentioned processes. In order to circumvent that problem, realistic numerical modeling seems a particularly useful tool for studying the various sources of the EUC.

[9] This study will specifically address the following questions: how do the northern and southern hemisphere sources organize to shape the EUC waters along its path to the eastern Pacific? Which density layers are conveyed from each source within the EUC? Our results will help improve our characterization of the biogeochemical supply toward the eastern equatorial upwelling region.

[10] The present study focuses on the sources of the EUC along its pathway from $156^{\circ} \mathrm{E}$ to $140^{\circ} \mathrm{W}$, using a $1 / 4^{\circ}$ resolution Ocean General Circulation Model (OGCM) and a quantitative Lagrangian analysis. The absolute and relative contributions of the various sources composing the EUC were investigated in order to improve our knowledge about the fate of the water masses conveyed by the LLWBCs that potentially carry an important part of the nutrients to the HNLC area.

[11] Section 2 describes the numerical tools used in this study. The EUC sources and related transports from $156^{\circ} \mathrm{E}$ to $140^{\circ} \mathrm{W}$ are presented in section 3 as well as the distribution of the various sources within the EUC at $165^{\circ} \mathrm{E}$.
Section 4 focuses on the water density characterization of the EUC sources downstream and within the EUC at $165^{\circ} \mathrm{E}$. We discuss the results and conclusions in section 5.

\section{Methodology}

\subsection{The OGCM}

\subsubsection{Description}

[12] We used the global interannual reference simulation (47 years, from 1958 to 2004) of the DRAKKAR project, referred to as "ORCA025-G70" [Barnier et al., 2006]. The model had a $0.25^{\circ}$ eddy-permitting horizontal resolution. The vertical grid had 46 levels, with a resolution ranging from $6 \mathrm{~m}$ near the surface to $250 \mathrm{~m}$ at $5750 \mathrm{~m}$. The depth of the bottom cell was variable (the so-called "partial-step") and was adjusted to match the true depth of the ocean for a better representation of small topographic slopes. The diffusion of tracers was performed along isopycnal surfaces through a Laplacian operator while dissipation of momentum was performed along geopotential surfaces using a biharmonic operator. The horizontal eddy viscosity and diffusivity coefficients were $300 \mathrm{~m}^{2} \mathrm{~s}^{-1}$ and $-1.510^{11} \mathrm{~m}^{4}$ $\mathrm{s}^{-2}$ at the equator, respectively. They decreased poleward proportionally to the size and the cubic size of the model grid cells, respectively. The vertical eddy viscosity and diffusivity coefficients were computed from a 1.5-order turbulent closure scheme based on a prognostic equation for the turbulent kinetic energy (TKE) [Blanke and Delecluse, 1993] and a diagnostic equation for the dissipation and mixing turbulent length scales.

[13] Surface wind stresses and heat fluxes were computed from the CORE bulk formulae [Large and Yeager, 2004], which used data from ERA40 [Uppala et al., 2005] for years 1958 to 2001, and ECMWF analysis for years 2002-2004. The change in 2002 resulted in a spurious adjustment of the upper ocean especially in the tropics [Molines et al., 2006]. To avoid this problem in our study, we limited our analysis to the end of 2001. The initial conditions for temperature and salinity were derived from Levitus et al.'s [1998] climatological data set for midlatitudes and low latitudes. Model outputs consisted of 5 day means. Note that with this spatial resolution, the St. George's Channel in the Bismarck Archipelago was closed and Vitiaz Strait was $630 \mathrm{~m}$ deep and $55 \mathrm{~km}$ wide at the surface. The ORCA025-G70 simulation has been widely used (http://www.drakkar-ocean.eu/) and we refer the reader to Molines et al. [2006] for more details on the simulation.

\subsubsection{Validation}

[14] The realism of our simulation was first assessed by comparing the simulated currents to observations. Along the PNG coast, current observations were available from a mooring deployed during a 5 year period from 1995 to 2000 [Ueki et al., 2003]. At the equator, zonal current observations were available from the TAO-TRITON array [Hayes et al., 1991; McPhaden, 1988]. At some equatorial sites $\left(147^{\circ} \mathrm{E}, 156^{\circ} \mathrm{E}, 165^{\circ} \mathrm{E}, 170^{\circ} \mathrm{W}, 140^{\circ} \mathrm{W}\right.$ and $\left.110^{\circ} \mathrm{W}\right)$, acoustic Doppler current profilers (ADCP) and/or mechanical current meters were deployed and measured ocean currents down to $300 \mathrm{~m}$. Owing to instrumental failure, the time series have missing values at some times and depths. For the purpose of comparison with the model outputs, the daily current observations were averaged into 5 day bins, and the 


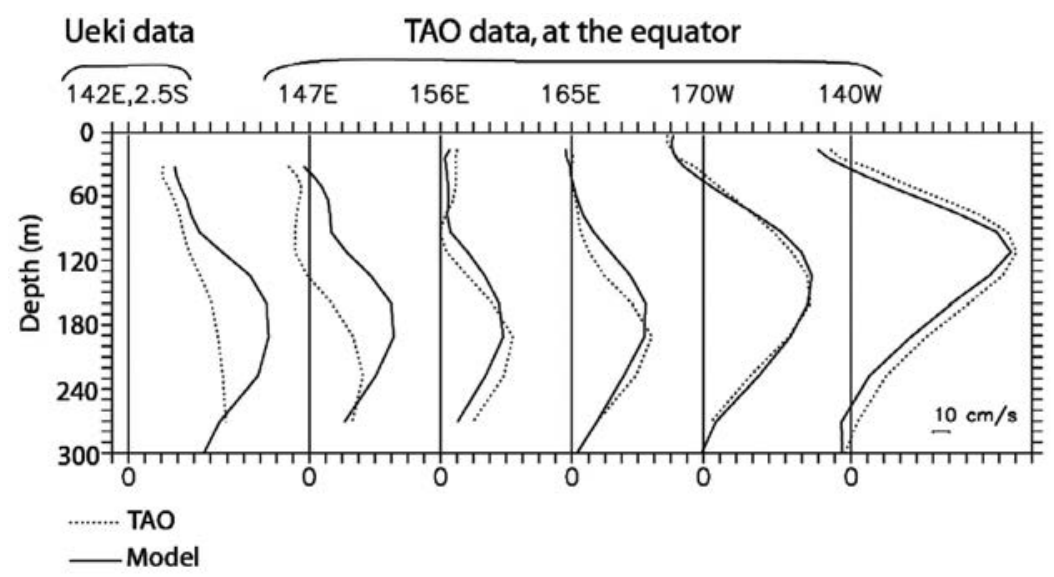

Figure 2. Dotted lines represent mean vertical profile of current speed from Ueki et al. [2003] data $\left(142^{\circ} \mathrm{E}-2.5^{\circ} \mathrm{S}\right.$, along the New Guinea coast) and mean vertical profiles of zonal velocity for Tropical Atmosphere Ocean (TAO) data $\left(147^{\circ} \mathrm{E}, 156^{\circ} \mathrm{E}, 165^{\circ} \mathrm{E}, 170^{\circ} \mathrm{W}\right.$, and $140^{\circ} \mathrm{W}$, at the equator), compared with equivalent information from the model (solid lines). One graduation along the horizontal axis is $10 \mathrm{~cm} \mathrm{~s}^{-1}$.

simulated zonal currents were extracted from the model at the Tropical Atmosphere Ocean (TAO) mooring locations at every date for which observed data were available during the 1990-2001 period.

[15] Figure 2 shows the resulting mean vertical profiles for observed and simulated zonal currents at $147^{\circ} \mathrm{E}, 156^{\circ} \mathrm{E}$, $165^{\circ} \mathrm{E}, 170^{\circ} \mathrm{W}$, and $140^{\circ} \mathrm{W}$, showing the EUC structure. It also shows the mean observed and simulated horizontal velocity magnitude at $142^{\circ} \mathrm{E}-2.5^{\circ} \mathrm{S}$ (PNG mooring). Currents simulated by the model showed an excellent agreement with data at $170^{\circ} \mathrm{W}$ and $140^{\circ} \mathrm{W}$. They are also well reproduced at $156^{\circ} \mathrm{E}$ and $165^{\circ} \mathrm{E}$, with a fair simulation of the EUC mean velocity core, although the core was slightly deeper in the observations. Contrastingly, mean zonal currents were not well simulated at $147^{\circ} \mathrm{E}-0^{\circ} \mathrm{N}$. At this location, the modeled EUC was much stronger and its core was much

a)

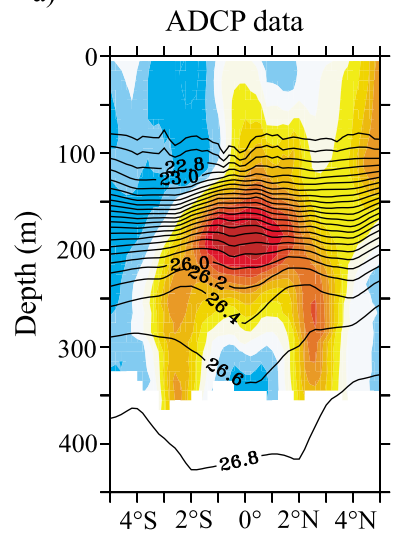

$165^{\circ} \mathrm{E}$

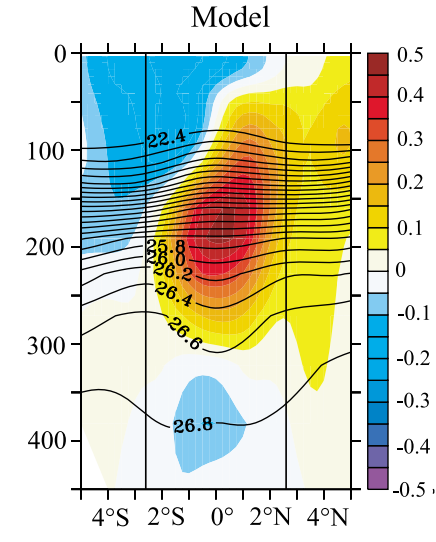

Latitude

shallower than observed. The cause and implications of this discrepancy will be discussed later. At $142^{\circ} \mathrm{E}-2.5^{\circ} \mathrm{S}$, the NGCU core was poorly simulated. However, a small shift in the core of the NGCU relative to the model bathymetry or mooring position could explain large differences in current strength.

[16] Meridional sections of shipboard ADCP (SADCP) mean zonal velocity [Johnson et al., 2002] were compared with the simulated mean zonal velocity at $165^{\circ} \mathrm{E}$ and $140^{\circ} \mathrm{W}$ in Figure 3. Data were taken mostly in the 1990s and correspond to 172 synoptic meridional CTD/ADCP sections in the tropical Pacific [Johnson et al., 2002]. For both sections, mean isopycnals (data from Johnson et al. [2002]) were also plotted. At $165^{\circ} \mathrm{E}$, both observed and simulated EUC cores were located between $\sigma_{\theta}=25 \mathrm{~kg} \mathrm{~m}^{-3}$ and $\sigma_{\theta}=25.8 \mathrm{~kg} \mathrm{~m}^{-3}$. The transition from the EUC to the underlying Equatorial

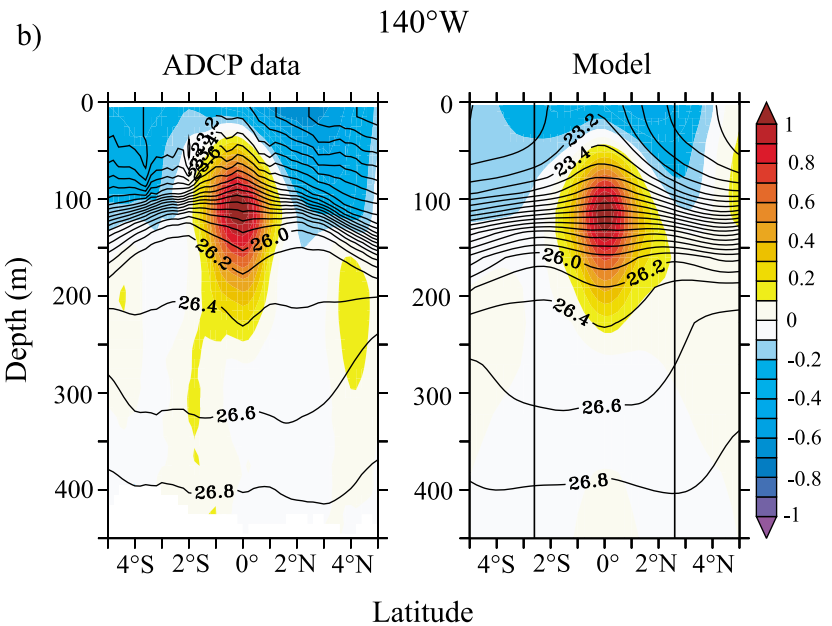

Figure 3. Meridional sections of mean zonal velocity expressed in $\mathrm{m} \mathrm{s}^{-1}$ at (a) $165^{\circ} \mathrm{E}$ and (b) $140^{\circ} \mathrm{W}$. At both longitudes, Johnson et al. [2002] data (ADCP data) are compared to the OGCM velocity averaged over the 1970-2001 period (Model). Isopycnals are superimposed in black with a $0.2 \mathrm{~kg} \mathrm{~m}^{-3}$ contour interval. The dashed isopycnal refers to $\sigma_{\theta}=25.0 \mathrm{~kg} \mathrm{~m}^{-3}$. The two black vertical lines show the latitude range that bounds our definition of the EUC (see section 3.1). 

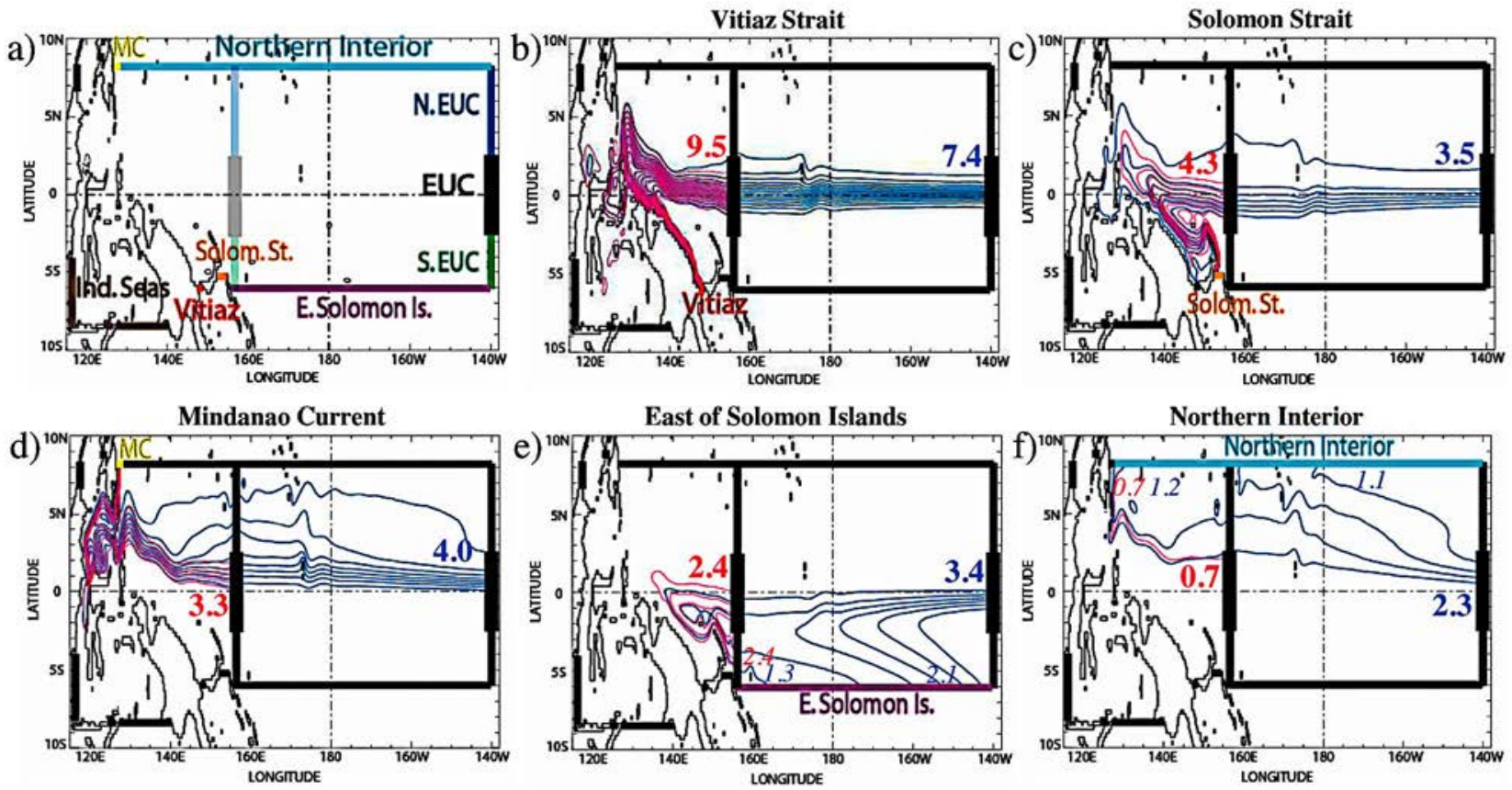

Figure 4. (a) Control sections used in the Lagrangian backward experiment started at $140^{\circ} \mathrm{W}$. The translucent sections show the eastern limits for the experiment started at $156^{\circ} \mathrm{E}$, with other sections unchanged. The domain of integration is bounded by eight interception sections (in color) and an injection section (across the EUC, in black) that also acts as an interception section over its whole extent. The Lagrangian stream function of the mass transfer, associated with each source and integrated both in time and depth, is shown with a $0.5 \mathrm{~Sv}$ contour interval as thin pink lines and thick blue lines for the EUC studied at $156^{\circ} \mathrm{E}$ and at $140^{\circ} \mathrm{W}$, respectively, for waters originating from (b) Vitiaz Strait, (c) Solomon Strait, (d) Mindanao Current, (e) east of Solomon Islands, and (f) northern interior Pacific Ocean. The transport value of each source is reported close to the EUC section, at $156^{\circ} \mathrm{E}$ and $140^{\circ} \mathrm{W}$, in bold pink and bold blue, respectively (in Sv). The transport values in italic detail, for sections representing interior ocean sources, the part that eventually flows along the boundaries and the part that flows through interior pathways (in Sv).

Intermediate Current (EIC) was slightly too deep in the model. The main discrepancy concerns the observed well developed Subsurface Countercurrents (SCCs), also called Tsuchiya Jets, between $200 \mathrm{~m}$ and $350 \mathrm{~m}$ depth at $3^{\circ} \mathrm{N}$ and $3^{\circ} \mathrm{S}$, which would require higher vertical resolution and smaller viscosity in the model for appropriate representation [Marin et al., 2000; Stockdale et al., 1998]. In the central Pacific, at $140^{\circ} \mathrm{W}$, the width, depth, current intensity, and density ranges of the EUC were in very good agreement with observations and the SEC was also realistically reproduced in the model.

[17] To conclude, the location and intensity of the mean modeled LLWBCs and EUC (especially east of $147^{\circ} \mathrm{E}$ ) were correctly simulated. The transports and locations of the western boundary currents in Vitiaz Strait, Solomon Strait, and along the Mindanao coast (not shown) were also consistent with previous observations and transport estimates [Cravatte et al., 2011; Wijffels et al., 1995; Dutrieux et al., 2008]. These model performances allowed us to analyze water pathways and transports between the LLWBCs and the EUC with some confidence in the robustness of our results. The implications of our findings of the discrepancies between the modeled and observed currents will be discussed in section 5 .

\subsection{The ARIANE Lagrangian Tool}

[18] ARIANE is an off-line diagnostic tool dedicated to the computation of 3D streamlines in a given velocity field (as the output of an OGCM) and subsequent water masses analyzes on the basis of multiple particle trajectories [Blanke and Raynaud, 1997; Blanke et al., 1999]. In this study, we used 5 day average outputs of the zonal and meridional velocity fields as well as salinity (S) and temperature (T) fields. The temporal integration of these fields allows tracing of the average origin (backward integration) or fate (forward integration) of selected water masses. Here, the average behavior was determined thanks to the injection of particles over a long period ( 20 years) that integrated the interannual variability present in the simulated data. Turbulent diffusion processes were not used to calculate the trajectories, as particles are only advected by the modeled velocity. Instead, effects of turbulent mixing on the followed water masses were provided implicitly by the along-trajectory changes in tracer properties ( $\mathrm{T}$ and $\mathrm{S}$ ).

[19] Using the ORCA025-G70 "C" grid [see Arakawa, 1972] we defined several segments that form, with the land grid cells, a closed oceanic domain. One of these segments was used as the injection segment, where particles were seeded at each time step for the grid cells where the 


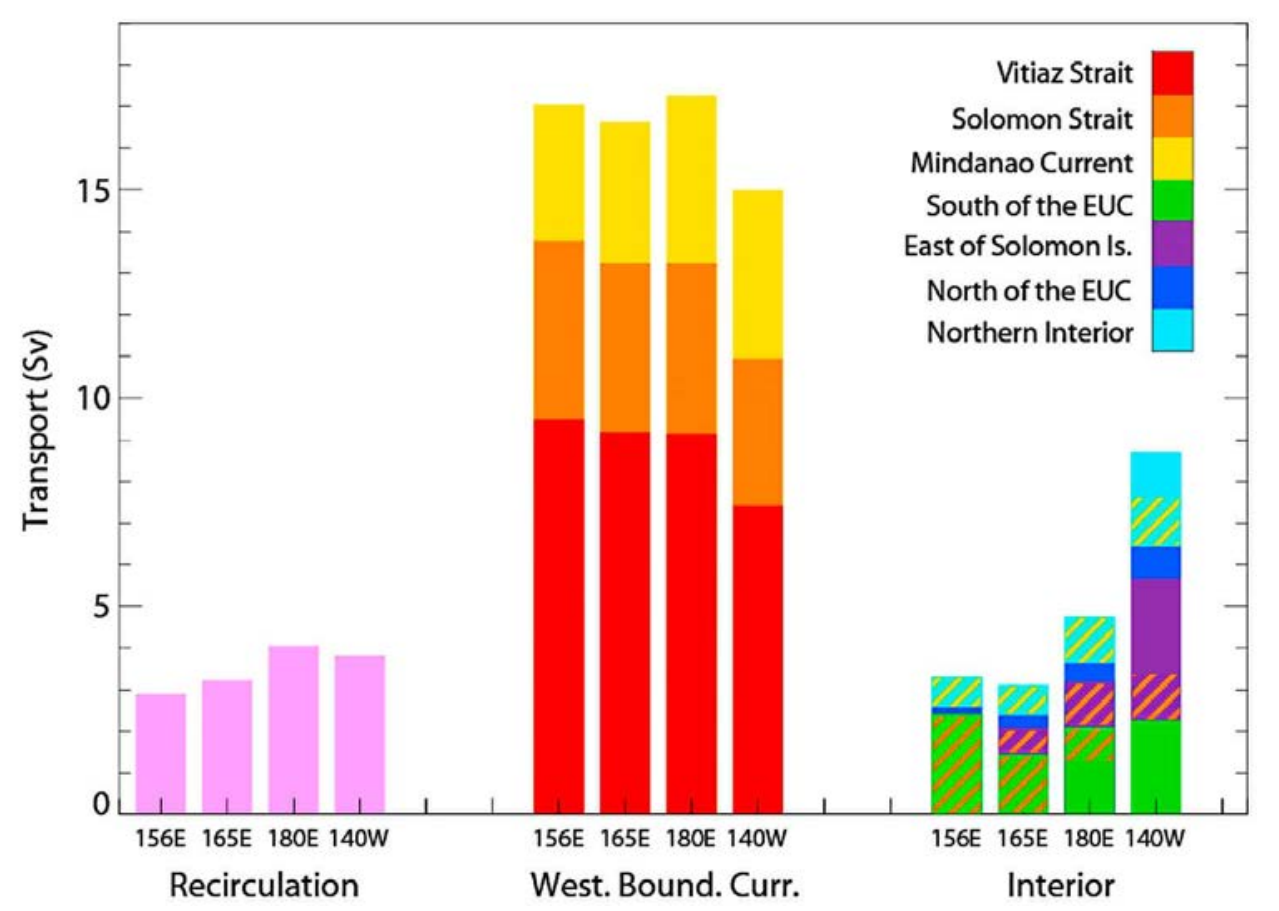

Figure 5. Contribution (in Sv) of the different sources to the EUC transport considered at $156^{\circ} \mathrm{E}, 165^{\circ} \mathrm{E}$, $180^{\circ} \mathrm{E}$, and $140^{\circ} \mathrm{W}$. "West. Bound. Curr." means Western Boundary Currents and includes the origins Vitiaz Strait (red bars), Solomon Strait (orange), and Mindanao Current (yellow). The "Interior Ocean" contributions, i.e., south of the EUC (green bars), east of the Solomon Islands (purple), north of the EUC (blue), and Northern Interior (cyan), are shown in the bottom right-hand corner. The recirculation, defined at the end of section 2 , is shown in the bottom left-hand corner. The orange-hatched shading specifies the fraction of the sources that is eventually conveyed by the NICU and that must be added to the Solomon Strait contribution for the full estimation of the NICU source. In a similar way, the yellowhatched shading specifies the fraction of the sources that contributes ultimately to the Mindanao Current transport.

transverse velocity was inward the domain (i.e., these particles will enter the domain the following time step). Other segments were "interception" segments (see Figure 4a for the segment locations and details). For a backward integration from the injection section, they represented the locations of the diverse origins of the followed water masses. Following Blanke et al. [1999], each seeded particle was bearing an infinitesimal transport and the sum of all the transports amounts to the available inflow. Owing to water incompressibility, a given particle conserves its infinitesimal mass along its trajectory. A water mass can be defined by a set of particles that match selected position, velocity or density criterion. Thus, this mass-preserving method allows quantifying the transport of a given water mass, adding up the elementary transports of the particles that compose it. Note that the segment where particles were injected also acts as an interception section over its whole extent. It was used to quantify the water flowing initially westward in the SEC or in the EIC, and joining the EUC afterward. This zonal sea-saw motion is referred to as recirculation (see Figure 5).

\section{Pathways of the EUC Sources}

\subsection{Experiments}

[20] The main difficulty in estimating the transport of the EUC is definitional: there are several eastward currents close to the EUC (Figures 1 and 3), and it is somewhat arbitrary to define the boundaries between the EUC, the North Equatorial Countercurrent (NECC) to the north, the SCCs on both flanks and the Equatorial Intermediate Current (EIC) below. In this study, we defined the EUC as the eastward flow greater than $0.1 \mathrm{~m} \mathrm{~s}^{-1}$, in the latitude band from $2.625^{\circ} \mathrm{N}$ to $2.625^{\circ} \mathrm{S}$ and in the density range from $22.4 \mathrm{~kg}$ $\mathrm{m}^{-3}$ to $26.8 \mathrm{~kg} \mathrm{~m}^{-3}$ (Figure 3 ). The shallower limit in density was chosen to distinguish the EUC flow from the eastward surface jets occasionally generated by westerly winds. The deeper limit in density was chosen to avoid inclusion of waters from the westward EIC that reverses seasonally [Marin et al., 2010]. A stronger constraint for the magnitude of the zonal velocity, added to a density definition, results in a loss of waters at the edge of the EUC. On the contrary, we would get some intrusions from the NECC or from the EIC within our EUC definition if only the sign of the velocity was imposed.

[21] Four experiments were performed, in which particles were injected into the EUC at $156^{\circ} \mathrm{E}, 165^{\circ} \mathrm{E}, 180^{\circ}$, and $140^{\circ} \mathrm{W}$, respectively, and integrated backward in time until they reach one of the 8 source sections defined in Figure 4 and Table 1. Particles were injected from the end of 2001 to the beginning of 1982 (i.e., for 20 years), and followed backward for 11 years. These time ranges were chosen to have a long enough temporal integration so that a maximum 
Table 1. Coordinates of the Sections Delimiting Our Domain

\begin{tabular}{|c|c|c|}
\hline Sections & Longitude & Latitude \\
\hline EUC (recirculation) & $\begin{array}{r}155.6^{\circ} \mathrm{E} \text { or } 164.9^{\circ} \mathrm{E} \text { or } \\
179.9^{\circ} \mathrm{E} \text { or } 140.1^{\circ} \mathrm{W}\end{array}$ & $2.624^{\circ} \mathrm{N}-2.624^{\circ} \mathrm{S}$ \\
\hline Vitiaz Strait & $147.4^{\circ} \mathrm{E}-148.9^{\circ} \mathrm{E}$ & $5.865^{\circ} \mathrm{S}$ \\
\hline Solomon Strait & $152.1^{\circ} \mathrm{E}-154.6^{\circ} \mathrm{E}$ & $5.118^{\circ} \mathrm{S}$ \\
\hline Indonesian Seas & $\begin{array}{l}124.4^{\circ} \mathrm{E}-126.4^{\circ} \mathrm{E} \\
127.1^{\circ} \mathrm{E}-140.4^{\circ} \mathrm{E}, \\
116.4^{\circ} \mathrm{E} \\
117.6^{\circ} \mathrm{E} \\
119.9^{\circ} \mathrm{E}-122.9^{\circ} \mathrm{E} \\
123.1^{\circ} \mathrm{E}\end{array}$ & $\begin{array}{c}8.345^{\circ} \mathrm{S}, \\
8.345^{\circ} \mathrm{S}, \\
8.345^{\circ} \mathrm{S}-3.872^{\circ} \mathrm{S}, \\
6.610^{\circ} \mathrm{N}-8.345^{\circ} \mathrm{N}, \\
10.32^{\circ} \mathrm{N}, \\
8.593^{\circ} \mathrm{N}-9.087^{\circ} \mathrm{N}\end{array}$ \\
\hline Mindanao Current & $126.4^{\circ} \mathrm{E}-127.4^{\circ} \mathrm{E}$ & $8.098^{\circ} \mathrm{N}$ \\
\hline East of Solomon Islands & $\begin{array}{l}155.4^{\circ} \mathrm{E}-164.9^{\circ} \mathrm{E} \\
\text { or } 155.4^{\circ} \mathrm{E}-179.9^{\circ} \mathrm{E} \\
\text { or } 155.4^{\circ} \mathrm{E}-140.1^{\circ} \mathrm{W}\end{array}$ & $5.865^{\circ} \mathrm{S}$ \\
\hline Northern Interior & $\begin{array}{l}127.4^{\circ} \mathrm{E}-155.6^{\circ} \mathrm{E} \\
\text { or } 127.4^{\circ} \mathrm{E}-164.9^{\circ} \mathrm{E} \\
\text { or } 127.4^{\circ} \mathrm{E}-179.9^{\circ} \mathrm{E} \\
\text { or } 127.4^{\circ} \mathrm{E}-140.1^{\circ} \mathrm{W}\end{array}$ & $8.098^{\circ} \mathrm{N}$ \\
\hline South of the EUC & $\begin{array}{r}155.6^{\circ} \mathrm{E} \text { or } 164.9^{\circ} \mathrm{E} \text { or } \\
179.9^{\circ} \mathrm{E} \text { or } 140.1^{\circ} \mathrm{W}\end{array}$ & $5.865^{\circ} \mathrm{S}-2.624^{\circ} \mathrm{S}$ \\
\hline North of the EUC & $\begin{array}{r}155.6^{\circ} \mathrm{E} \text { or } 164.9^{\circ} \mathrm{E} \text { or } \\
179.9^{\circ} \mathrm{E} \text { or } 140.1^{\circ} \mathrm{W}\end{array}$ & $2.624^{\circ} \mathrm{N}-8.098^{\circ} \mathrm{N}$ \\
\hline
\end{tabular}

of fluid particles exited the closed domain by one of the eight sections (see eleventh row in Table 2). The vertically integrated and time averaged stream functions obtained separately for each source are shown for $156^{\circ} \mathrm{E}$ and $140^{\circ} \mathrm{W}$ in Figure 4. The transport values of each EUC source are summarized for the four experiments in Table 2 and displayed in Figure 5.

\subsection{EUC Sources at $156^{\circ} \mathrm{E}$}

[22] A large majority of the EUC waters considered at $156^{\circ} \mathrm{E}$ passes first through the LLWBCs $(87 \%$, among which $13 \%$ originate from interior sections and flow ultimately via the LLWBCs, as specified by the yellow and orange hatches in Figure 5), whereas $12 \%$ originate from east of $156^{\circ} \mathrm{E}$, conveyed by westward currents, and recirculate within the EUC (Figure 5 and Table 2). The LLWBCs contribution comes mostly from the south. $40 \%$ of the EUC waters flow through Vitiaz Strait, within the NGCU, and $28 \%$ flow east of New Ireland within the NICU. The NICU is mainly fed by the flow exiting through Solomon Strait (4.3 Sv, $18 \%$ of the EUC waters), and directly by the SEC (2.4 Sv, $10 \%$ of the EUC waters). Thus, in our model, $58 \%$ of the EUC waters at $156^{\circ} \mathrm{E}$ pass first through the Solomon Sea. Only $18 \%$ of the EUC waters originate from the Mindanao Current.

[23] The pathways of the waters composing the EUC at $156^{\circ} \mathrm{E}$ are shown in Figure 4 (pink lines). They are quite complex. The flow originating from Vitiaz Strait (Figure 4b) overshoots the equator and splits into three different branches before retroflecting into the EUC.

[24] 1. The westernmost flow $(\sim 1.5-2 \mathrm{~Sv})$ retroflects southwestward into the Halmahera Sea (Figure 1), turns around the Halmahera coast, and recirculates into the Halmahera Eddy (HE) to reach the EUC. Its associated transport is well preserved, in absolute contribution, all along its eastward transport within the EUC. Such a pathway was already suggested by observations from Gordon and Fine [1996, Figure 1] and from Hautala et al. [1996] and was simulated in the BRAN model [Schiller et al., 2008].

[25] 2. The central flow $\left(\sim 3.5 \mathrm{~Sv}\right.$ at $\left.156^{\circ} \mathrm{E}\right)$ directly recirculates in the Halmahera Eddy (HE) after crossing the equator and reaches the EUC. This pathway is also consistent with former observations [e.g., Kashino et al., 1996] that reported intrusions of southern hemisphere saline waters as far north as $5^{\circ}-6^{\circ} \mathrm{N}$.

[26] 3. Finally, the main branch originating from Vitiaz Strait and feeding the EUC, i.e., the easternmost one $\left(\sim 4 \mathrm{~Sv}\right.$ at $\left.156^{\circ} \mathrm{E}\right)$, retroflects into the EUC north of the equator via the New Guinea Eddy (Figure 1) without recirculating in the HE.

[27] The NICU waters (Figures $4 \mathrm{c}$ and $4 \mathrm{e}$ ) are mostly advected westward toward the PNG coast before reaching the EUC. The whole flow through Solomon Strait (Figure 4c) is advected southwestward into the Bismarck Sea before being conveyed northwestward by the NGCU. Then, these Solomon Strait-originating waters follow the same pathway as the Vitiaz Strait water masses described above. The major part of the SEC vein joining the NICU

Table 2. Summary of the Source Transports Feeding the $156^{\circ} \mathrm{E}$ EUC, the $165^{\circ} \mathrm{E}$ EUC, the $180^{\circ} \mathrm{E}$ EUC, and the $140^{\circ} \mathrm{W}$ EUC

\begin{tabular}{|c|c|c|c|c|c|c|c|c|}
\hline \multirow[b]{2}{*}{ Sections } & \multicolumn{2}{|c|}{$156^{\circ} \mathrm{E}-\mathrm{EUC}$} & \multicolumn{2}{|c|}{$165^{\circ} \mathrm{E}-\mathrm{EUC}$} & \multicolumn{2}{|c|}{$180^{\circ} \mathrm{E}-\mathrm{EUC}$} & \multicolumn{2}{|c|}{$140^{\circ} \mathrm{W}-\mathrm{EUC}$} \\
\hline & $\mathrm{Sv}$ & $\%$ & $\mathrm{~Sv}$ & $\%$ & $\mathrm{~Sv}$ & $\%$ & Sv & $\%$ \\
\hline EUC (recirculation) & 2.9 & 12 & 3.2 & 14 & 4.0 & 15 & 3.8 & 14 \\
\hline Vitiaz Strait & $9.5^{*}$ & 41 & $9.2^{*}$ & 40 & $9.1^{*}$ & 35 & $7.4^{*}$ & 26 \\
\hline Solomon Strait & $4.3^{*}$ & 18 & $4.1^{*}$ & 18 & $4.1^{*}$ & 16 & $3.5^{*}$ & 13 \\
\hline Indonesian Seas & $0.1 *$ & 0 & $0.1^{*}$ & 0 & $0.1 *$ & 0 & $0.1^{*}$ & 0 \\
\hline Mindanao Current & $3.3^{*}$ & 14 & $3.4 *$ & 15 & $4.0^{*}$ & 15 & $4.0^{*}$ & 14 \\
\hline East of Solomon Islands & - & - & $0.6\left(0.6^{*}\right)$ & $3(3)$ & $1.1\left(1.1^{*}\right)$ & $4(4)$ & $3.4\left(1.3^{*}\right)$ & $12(5)$ \\
\hline South of the EUC & $2.4\left(2.4^{*}\right)$ & 10 & $1.5\left(1.5^{*}\right)$ & $6(6)$ & $2.1\left(0.8^{*}\right)$ & $8(3)$ & 2.3 & 8 \\
\hline Northern Interior & $0.7\left(0.7^{*}\right)$ & $3(3)$ & $0.7\left(0.6^{*}\right)$ & $3(3)$ & $1.1\left(1.0^{*}\right)$ & $4(4)$ & $2.3(1.2 *)$ & $8(4)$ \\
\hline North of the EUC & 0.2 & 1 & 0.3 & 1 & 0.3 & 2 & 0.8 & 3 \\
\hline Surface & 0.0 & 0 & 0.0 & 0 & 0.0 & 0 & 0.0 & 0 \\
\hline Temporal interception & 0.1 & 0 & 0.1 & 0 & 0.2 & 1 & 0.5 & 2 \\
\hline Total & 23.4 & 100 & 23.1 & 100 & 26.3 & 1000 & 28.0 & 100 \\
\hline LLWBCs & $20.3 *$ & 87 & $19.5^{*}$ & 84 & $20.5^{*}$ & 78 & $17.5^{*}$ & 63 \\
\hline Interior pathways & 0.2 & 1 & 0.4 & 2 & 1.8 & 7 & 6.3 & 23 \\
\hline
\end{tabular}

\footnotetext{
${ }^{a}$ Transports on the left are in sverdrups, and those on the right are in percent. Numbers in parentheses show the fraction of transport that transits ultimately through the NICU and the Mindanao Current. The "temporal interception" criterion corresponds to transport that did not reach any section before the end of the temporal integration. Asterisks refer to transport conveyed by the LLWBCs; the total of this transport is given in the thirteenth row. Contribution of Interior Ocean off the equator is given in the fourteenth row.
} 
along the New Ireland coast (2 Sv out of $2.4 \mathrm{~Sv}$ ) follows about the same pathway as the flow exiting from Solomon Strait (Figure 4e). The remaining $0.4 \mathrm{~Sv}$ retroflects into the EUC north of New Ireland. This pattern differs from the results of P. Dutrieux et al. (Direct measurements of intermediate and upper ocean currents in the western tropical Pacific, manuscript in preparation, 2011) and Melet et al. [2010a]. Indeed, the latter study estimates that $3 / 5$ of the NICU directly retroflects in the EUC north of New Ireland. Here, less than $10 \%$ of the NICU waters follow this pathway.

[28] The thermocline waters that feed the EUC from the Mindanao Current (Figures 4d and 4f) mainly flow within the Celebes Sea, feeding the Indonesian Throughflow, before bifurcating toward the EUC through the northern part of the HE toward the EUC. This is fully consistent with previous observations [Fine et al., 1994; Kashino et al., 1996; Lukas et al., 1996].

[29] The travel time of water masses from their sources to the EUC at $156^{\circ} \mathrm{E}$ varies between one and two years depending on their route. Half of the particles conveyed by the southern LLWBCs reach the EUC at $156^{\circ} \mathrm{E}$ in about 15 16 months. Most of the waters originating in Vitiaz Strait travel in around 9 months. For the NICU origin, waters reach the EUC in about either 4 months or 1 year. The 4 month route corresponds to NICU water masses retroflecting into the EUC north of New Ireland: this is the fastest and shortest western boundary route to the EUC of our study. The 1 year path corresponds to the NICU route via the NGCU. Mindanao Current water masses have a longer travel time than the southern hemisphere sources. Half of the particles reach the EUC at $156^{\circ} \mathrm{E}$ after 2 years of transit.

[30] The EUC recirculation represents the transport that flows back to the initial section, being converted or not into another hydrological class than the one defined at the injection. Whereas the injection over the EUC at $165^{\circ} \mathrm{E}$ is controlled by density and velocity criteria, the whole vertical plan at $165^{\circ} \mathrm{E}$, from $2.625^{\circ} \mathrm{N}$ to $2.625^{\circ} \mathrm{S}$ and from the surface to the ocean bottom, becomes an interception section for the particles integrated backward in time. The recirculation around $165^{\circ} \mathrm{E}$ is associated with waters flowing initially westward at $165^{\circ} \mathrm{E}$ in the SEC or in the EIC, and joining the EUC later. Half of particles recirculating between the SEC and the EUC remain during a year within the domain of integration. The particles participating in the lower recirculation, between the EIC and the EUC, have a longer median age, equal to one and a half year.

\subsection{From $156^{\circ} \mathrm{E}$ to $140^{\circ} \mathrm{W}$ : Evolution of the Transports of the EUC Sources}

[31] The source contributions of the EUC, taken at different longitudes, are represented in Figure 5. This allows following the evolution of the relative importance of the EUC sources along the equator, from its origin in the western Pacific to $140^{\circ} \mathrm{W}$. One must be attentive here about the distinction between "Western Boundary Currents" versus "Interior Ocean." Indeed, "Interior Ocean" refers to sections located in the open ocean. However, a part of the southern "Interior Ocean" transport converges toward the New Ireland coast and is conveyed ultimately by the NICU (orange hatched portions in Figure 5). Consequently, this transport should be added to the Solomon Strait transport for the estimation of NICU supplies. A similar remark applies for the yellow-hatched portion of the northern interior transport that flows within the MC (Figure 5).

\subsubsection{Evolution of the Interior Pathways' Contributions to the EUC}

[32] At $156^{\circ} \mathrm{E}$ and $165^{\circ} \mathrm{E}$, almost all the waters that compose the EUC passed first through the LLWBCs (Figure 5). As expected, contributions from interior oceanic pathways increase progressively from $156^{\circ} \mathrm{E}$ to $140^{\circ} \mathrm{W}$, and become significant only east of $180^{\circ}$. At $140^{\circ} \mathrm{W}, 32 \%$ of the EUC sources originate from interior sections among which $23 \%$ follow interior pathways all along their route (see nonhatched interior fraction in Figure 5 and Table 2). Interior southern supplies are larger than their northern counterpart. This hemispheric difference is likely due to the existence of a high potential vorticity ridge in the North Pacific, located under the Intertropical Convergence Zone, which limits the connection between the Northern Interior Pacific Ocean and the equator [e.g., Liu et al., 1994; Lu and McCreary, 1995; Johnson and McPhaden, 1999; Fukumori et al., 2004].

\subsubsection{Evolution of the Western Boundary}

\section{Contributions}

[33] Interestingly, the Mindanao Current contribution increases between $156^{\circ} \mathrm{E}$ and $140^{\circ} \mathrm{W}$ (Figure 5 and Table 2). However, only $50 \%$ of the MC-originating waters flowing within the EUC at $140^{\circ} \mathrm{W}$ flow already in the EUC at $156^{\circ} \mathrm{E}$. The other $50 \%$ are first conveyed eastward by the NECC, converging progressively toward the equator after $175^{\circ} \mathrm{E}$, before they eventually enter the EUC (Figures $4 d$ and $4 \mathrm{f}$ ). This is in agreement with the results of Johnson and McPhaden [1999].

[34] Surprisingly, the Vitiaz Strait contribution to the EUC transport decreases from $9.5 \mathrm{~Sv}$ to $7.4 \mathrm{~Sv}$ between $156^{\circ} \mathrm{E}$ and $140^{\circ} \mathrm{W}$, meaning that $2.1 \mathrm{~Sv}$ of Vitiaz Strait-originating waters exit the EUC during its eastward advection from $156^{\circ} \mathrm{E}$ to $140^{\circ} \mathrm{W}$. More generally, a decrease of $20 \%$ of the southern LLWBCs supplies is observed between $156^{\circ} \mathrm{E}$ and $140^{\circ} \mathrm{W}$, partly compensated by $\mathrm{MC}$ supplies. Actually, about $1 / 3$ of the EUC waters coming from each western boundary section at $156^{\circ} \mathrm{E}$ does not reach $140^{\circ} \mathrm{W}$.

[35] Forward Lagrangian experiments were performed for each of the LLWBCs' sources to identify where and how these waters are leaking from the EUC between $156^{\circ} \mathrm{E}$ and $140^{\circ} \mathrm{W}$. We isolated the waters that feed the $156^{\circ} \mathrm{E}$ EUC from each LLWBCs' section, and advected them from $156^{\circ} \mathrm{E}$ to $140^{\circ} \mathrm{W}$ (not shown). The major part of the LLWBCs' waters present within the EUC at $156^{\circ} \mathrm{E}$ but not anymore at $140^{\circ} \mathrm{W}$ exit the EUC through the lateral limits at $2.625^{\circ} \mathrm{N}$ and $2.625^{\circ} \mathrm{S} .40 \%$ of the transport losses of the Vitiaz Strait source leak out at the northern EUC boundary, $30 \%$ at the southern one, and $20 \%$ recirculates in the SEC or the EIC. This spatial distribution of Vitiaz Strait losses is coherent with the fact that a larger part of this source crosses the equator north of PNG and transits within the EUC in its northern part. $76 \%$ of MC source transport losses leak out of the EUC to the north whereas $56 \%$ of the loss of NICU source transport leaks out to the south, suggesting a greater return of the northern sources to their own hemisphere. These lateral losses mainly result from equatorial divergence of the waters located above the EUC core. 
Effective velocity $\left(\mathrm{m} \mathrm{s}^{-1}\right)$
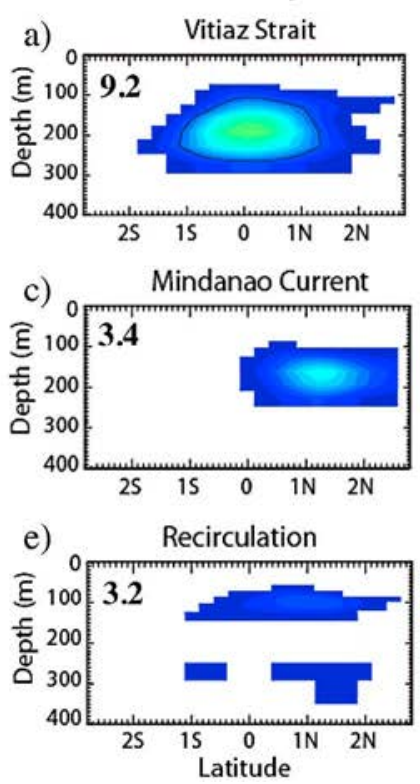
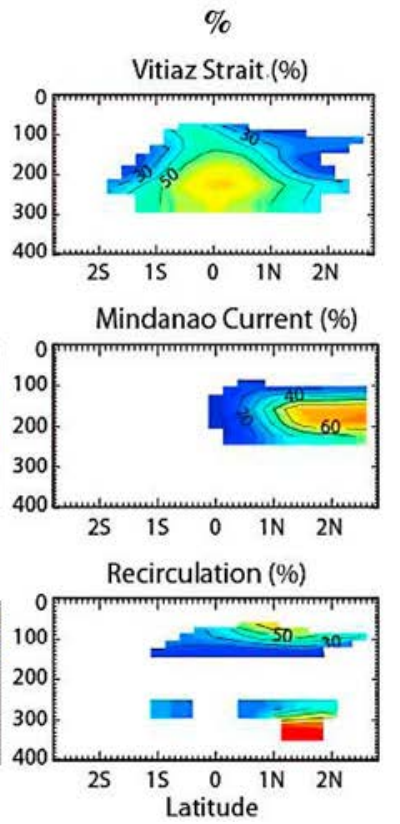

Effective velocity $\left(\mathrm{m} \mathrm{s}^{-1}\right)$

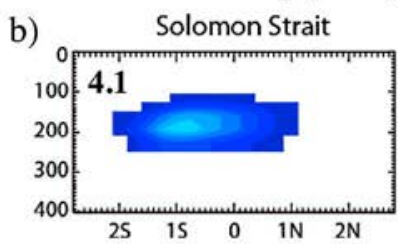

d) Southern Interior

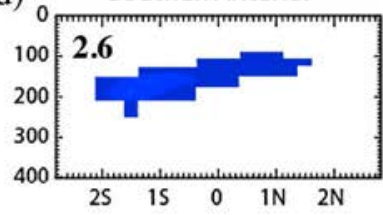

f) Total sources

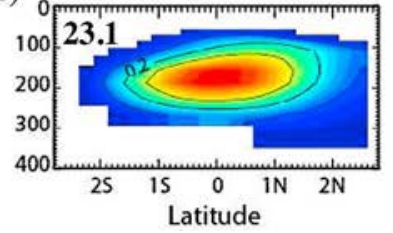

$\%$

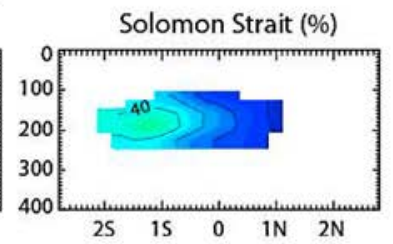

Southern Interior (\%)

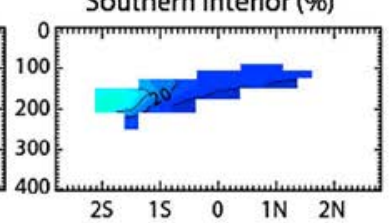

g)

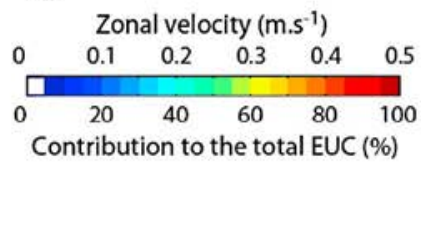

Figure 6. Contribution of the major sources to the EUC zonal velocity profile at $165^{\circ} \mathrm{E}$, expressed either as an "effective velocity" (left graphs, in $\mathrm{m} \mathrm{s}^{-1}$ ) or as a fraction of the local EUC velocity (right graphs, in percent): (a) Vitiaz Strait, (b) Solomon Strait, (c) Mindanao Current, (d) Southern Interior (east of Solomon Islands + south of the EUC), and (e) recirculation. Regions where the velocity is less than $0.025 \mathrm{~m} \mathrm{~s}^{-1}$ are blanked out. The "effective velocity" is obtained by the remapping on the injection section of the infinitesimal transports carried by particles with a specific origin. (f) The sum of the individual velocity components provides the mean EUC zonal velocity profile. (g) Explanation of the color bar. The associated transport is reported (in Sv) on the top left corner of the total EUC and of the "effective velocity" of each source.

\subsection{Structure of the $\mathrm{EUC}$ at $165^{\circ} \mathrm{E}$ as a Function of Its Origins}

[36] The effective velocity $\left(\mathrm{m} \mathrm{s}^{-1}\right)$ contributions of the various sources of the EUC at $165^{\circ} \mathrm{E}$ are shown as a function of latitude and depth in Figure 6. For each source, a complementary graph shows its contribution as a percentage of the EUC transport.

[37] Interestingly, the water masses originating from the $\mathrm{MC}$ or Solomon Strait are confined to their respective hemispheres (Figures $6 \mathrm{~b}$ and $6 \mathrm{c}$ ), whereas the waters originating from the NGCU spread almost uniformly within the EUC (Figure 6a). More precisely, the EUC water masses flowing from the NGCU are characterized by a core centered on $190 \mathrm{~m}$ and extending from $110 \mathrm{~m}$ to $260 \mathrm{~m}$. They represent more than $60 \%$ of the total EUC transport between $0.5^{\circ} \mathrm{S}$ and $1^{\circ} \mathrm{N}$, between $180 \mathrm{~m}$ and $280 \mathrm{~m}$ depth. Thus, these waters constitute the major contribution to the EUC waters, especially at the equator and below $200 \mathrm{~m}$.

[38] At $165^{\circ}$ E, Solomon Strait waters feeding the EUC are centered on $0.9^{\circ} \mathrm{S}$ and $190 \mathrm{~m}$ depth where they represent more than $40 \%$ of the total EUC transport (Figure 6b). They extend from $2^{\circ} \mathrm{S}$ to $1^{\circ} \mathrm{N}$ and are the major component of the southern part of the EUC, between $100 \mathrm{~m}$ and $250 \mathrm{~m}$ depth. Waters from the SEC joining the NICU (Southern Interior section, Figure 6d) feed a small part of the $165^{\circ} \mathrm{E}$ EUC, with a core centered on $180 \mathrm{~m}$, between $2^{\circ} \mathrm{S}$ and $0.5^{\circ} \mathrm{S}$. They are even more confined in the southern EUC part than Solomon Strait-originating waters.
[39] The Mindanao Current water core is centered on $1.2^{\circ} \mathrm{N}$, at $170 \mathrm{~m}$ depth (Figure $6 \mathrm{c}$ ). This source extends from $0.2^{\circ} \mathrm{S}$ to the northern EUC boundary. It contributes to more than $50 \%$ of the total $165^{\circ} \mathrm{E}-\mathrm{EUC}$ transport, between 150 and $200 \mathrm{~m}$ depth, from the northern EUC boundary to $1^{\circ} \mathrm{N}$. Thus, MC waters are the main component of the northern EUC.

[40] Finally, a large part of the EUC transports at $165^{\circ} \mathrm{E}$ above $100 \mathrm{~m}$ depth or below 280-300 m depth consist of recirculating waters. Thus, the upper and lower depth limits of the EUC are mainly fed by the waters conveyed by the surrounding westward flowing currents such as the SEC or the EIC.

[41] Interestingly, these model results confirm the findings of Tsuchiya et al. [1989] based on water mass hydrological properties observed during WEPOCS cruises. Indeed, these authors suggested that the major source of the EUC is Coral Sea water transported by the NGCU. They also suggested that at $143^{\circ} \mathrm{E}$, between $0.5^{\circ} \mathrm{N}$ and $2^{\circ} \mathrm{N}$, the northern portion of the EUC contains northern hemisphere waters. Downstream, at $155^{\circ} \mathrm{E}$, their observations suggested that the southern portion of the EUC contains the tropical water flowing north of New Ireland and Solomon Islands.

[42] These findings are summarized in Figure 7, and the locations of the various sources within the EUC at several longitudes are represented in Figure 7. We decided to represent the dominant sources of the EUC as functions of depth and latitude (for more details about the definition of 

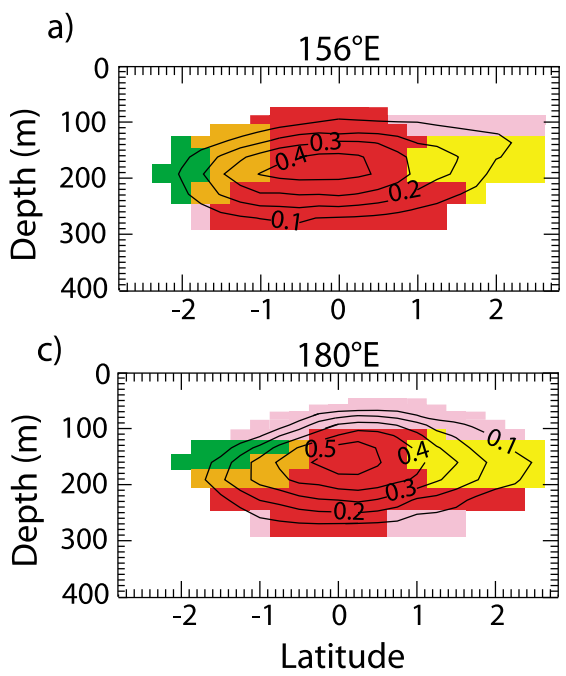

b)
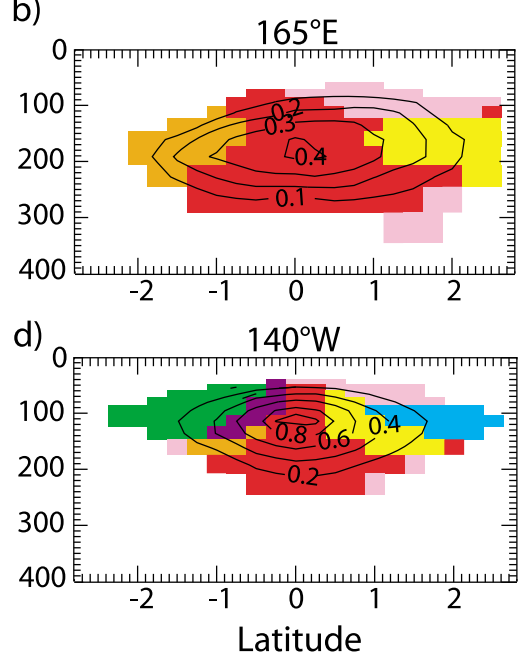

\section{Vitiaz Strait}

Solomon Strait

Mindanao Current

South of the EUC

East of Solomon Is.

Northern Interior

Recirculation

Figure 7. Recapitulative diagram of the dominant constituents of the EUC as a function of depth and latitude. The dominant source is the source that represents the largest transport within the grid cell. A red grid cell means that the largest part of transport comes from Vitiaz Strait. However, other sources can contribute to the transport existing in this grid cell, but their transports are smaller. The color code is the same as that in Figure 5, and the mean zonal velocity profile is contoured in black with a $0.1 \mathrm{~m} \mathrm{~s}^{-1}$ interval $\left(0.2 \mathrm{~m} \mathrm{~s}^{-1}\right.$ interval for $\left.140^{\circ} \mathrm{W}\right)$ for the EUC considered at (a) $156^{\circ} \mathrm{E}$, (b) $165^{\circ} \mathrm{E}$, (c) $180^{\circ} \mathrm{E}$, and (d) $140^{\circ} \mathrm{W}$.

"dominant source," see the caption of Figure 7). It shows that along its pathway from $156^{\circ} \mathrm{E}$ to $140^{\circ} \mathrm{W}$, the central EUC, throughout its depth, including its core, is dominated by Vitiaz Strait waters. These waters also dominate the lower part of the EUC, between $1^{\circ} \mathrm{S}$ and $1^{\circ} \mathrm{N}$, till $140^{\circ} \mathrm{W}$. Mindanao Current and Solomon Strait waters are dominant in their respective hemispheres, poleward of $0.8^{\circ}$, surrounding Vitiaz Strait waters around the EUC core depth. The contribution of Mindanao Current waters remains important in the northern part of the EUC till $140^{\circ} \mathrm{W}$, whereas the Solomon Strait waters are replaced by waters coming from southern interior pathways. The upper part of the EUC is mainly ventilated by SEC waters and, from east of $180^{\circ}$, by interior oceanic pathways in its southern part. An important conclusion is that the EUC waters below $200 \mathrm{~m}$ mostly originate from the NGCU all along the equator from $156^{\circ} \mathrm{E}$ to $140^{\circ} \mathrm{W}$. Below $280-300 \mathrm{~m}$, EUC waters mainly come from EIC recirculation. This is an important result for the issue of EUC micronutrient enrichment, and this point will be discussed in section 5 .

\section{Maxima Transport of Sources and Associated Densities}

[43] We now examine precisely the density range associated with each EUC source. For this purpose, we analyzed the transport distribution as a function of potential density at the origin sections and within the EUC at $165^{\circ} \mathrm{E}$ or at $140^{\circ} \mathrm{W}$ (Figure 8). Two different longitudes are considered because, as seen in section 3, interior oceanic sources do not contribute significantly to the EUC at $165^{\circ} \mathrm{E}$, whereas they represent $23 \%$ of the total EUC at $140^{\circ} \mathrm{W}$ (Table 2). Thus, the density distributions were examined at $165^{\circ} \mathrm{E}$ for the LLWBC sources and at $140^{\circ} \mathrm{W}$ for the interior oceanic sources (Figures $8 \mathrm{a}$ and $8 \mathrm{~b}$, respectively). Two curves are deduced from simulation with the Lagrangian tool representing the initial and final hydrological properties of each fluid particle. In Figure 8, gray histograms and black curves represent the transport distribution of all sources defined in Table 1, at their origin sections (coordinates in Table 1) and within the EUC, respectively. Colored histograms and curves show the same information for each LLWBC or interior source taken individually.

[44] Within the EUC at $165^{\circ} \mathrm{E}$ the total density distribution is characterized by a maximum of transport at $\sigma_{\theta}=26.2 \mathrm{~kg}$ $\mathrm{m}^{-3}$ (Figure 8a, black curve). This density is close to the lower EUC boundary defined at $\sigma_{\theta}=26.8 \mathrm{~kg} \mathrm{~m}^{-3}$. The transport distribution of waters flowing from Vitiaz Strait, maximum at $\sigma_{\theta}=26.2 \mathrm{~kg} \mathrm{~m}^{-3}$, is clearly determining the shape of the total transport distribution, although contributions from the Solomon Strait and Mindanao Current sources remain significant. However, the maximum of transport of these two sources, occurring at $\sigma_{\theta}=26.0 \mathrm{~kg} \mathrm{~m}^{-3}$, is slightly less dense than that of Vitiaz Strait (Figure 8a, orange and yellow curves). During its eastward transit (to $140^{\circ} \mathrm{W}$ ), the transport distribution of the total EUC remains maximum at $\sigma_{\theta}=26.2 \mathrm{~kg} \mathrm{~m}^{-3}$ but is less confined to denser waters as the distribution is seen to broaden (Figure 8b). The apparent shift toward lighter densities results from contributions of interior oceanic sources which are, at $140^{\circ} \mathrm{W}$, centered on $\sigma_{\theta}=24.2 \mathrm{~kg} \mathrm{~m}^{-3}$ (Figure 8b, black, green, and blue curves) that is within the EUC upper layer (Figure 3b).

[45] These results confirm the vertical distribution of the EUC sources illustrated in Figures 6 and 7, the densest waters originating from Vitiaz Strait. Moreover, these transport distributions show that (1) the EUC maximum of transport is located in its lower part, below $\sigma_{\theta}=25.0 \mathrm{~kg} \mathrm{~m}^{-3}$, and (2) this maximum of transport is primarily constituted by dense 

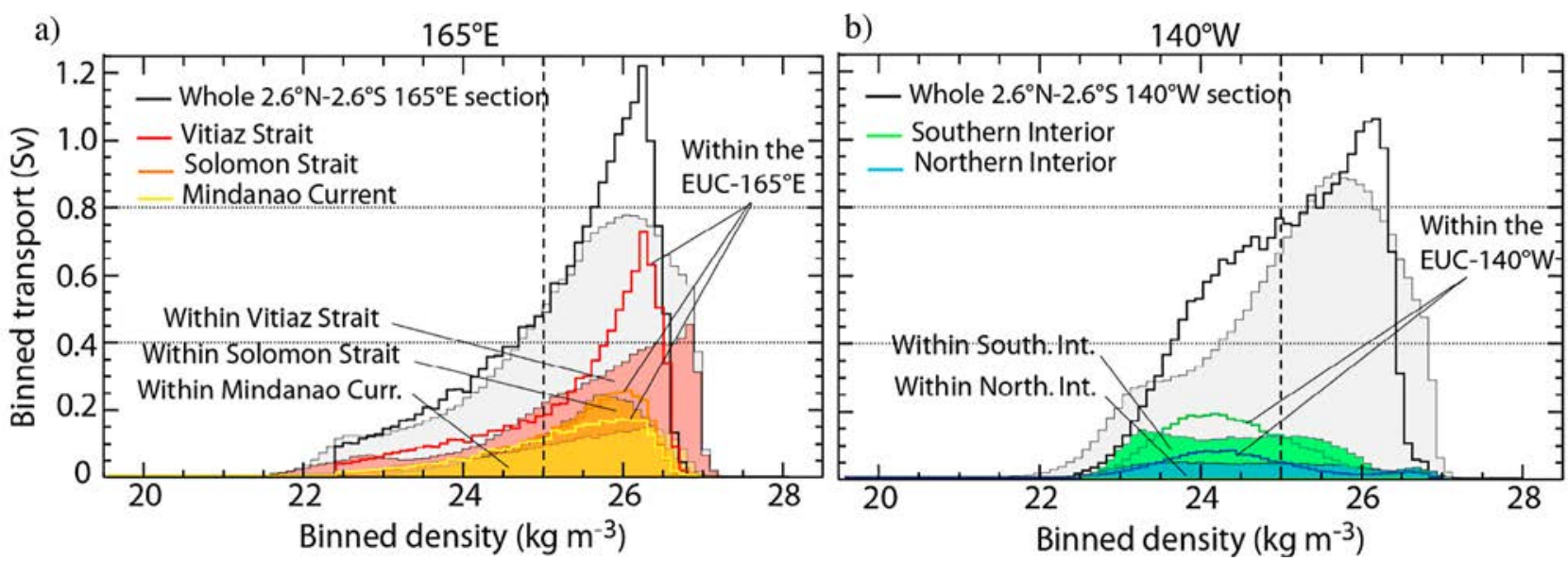

Figure 8. Contribution to the EUC transport binned as a function of density for (a) Vitiaz Strait (NGCU), Solomon Strait (NICU), and Mindanao Current and (b) Southern Interior and Northern Interior pathways. The first three sources, the LLWBCs, refer to the $165^{\circ} \mathrm{E}-\mathrm{EUC}$ experiment. The last two sources, flowing through the interior ocean, refer to the $140^{\circ} \mathrm{W}$-EUC experiment. The histograms refer to hydrological properties calculated at the sources, whereas the curves show the distribution within the EUC. The individual contribution of each source is shown in color, whereas the dark and gray refer to the sum of all the contributions, which amounts to the full EUC transport. The dashed line at $\sigma_{\theta}=25.0 \mathrm{~kg} \mathrm{~m}^{-3}$ represents the density limit between the upper and lower layers of the EUC. The bin interval is $0.1 \mathrm{~kg} \mathrm{~m}^{-3}$.

Vitiaz Strait waters. At $140^{\circ} \mathrm{W}$ the contribution of the light interior oceanic waters becomes significant whereas that of the dense LLWBC-originating waters decreases (Figure 5 and Table 2). Thus, the EUC transport is more equally distributed between the upper (light) and lower (dense) parts.

[46] In the origin sections, the transport distribution as a function of density is represented by the gray shaded (total) and colored histograms (each source contribution) in Figure 8 . Concerning the $165^{\circ} \mathrm{E}-\mathrm{EUC}$ experiment, the total transport distribution is maximum at $\sigma_{\theta}=26.0 \mathrm{~kg} \mathrm{~m}^{-3}$. This transport distribution also includes waters denser than the EUC ones (density range $26.5-27.0 \mathrm{~kg} \mathrm{~m}^{-3}$; Figure $8 \mathrm{a}$, gray histogram). These very dense waters come from the Vitiaz Strait before joining the EUC. They are also present in the EIC (not shown), before recirculating into the EUC at $165^{\circ} \mathrm{E}$. Indeed, in Vitiaz Strait the transport distribution is maximum at $\sigma_{\theta}=26.8 \mathrm{~kg} \mathrm{~m}^{-3}$ (Figure $8 \mathrm{a}$, red histogram). This is consistent with observations that show strong transport on deep isopycnals downstream of the Solomon Sea (W. S. Kessler, personal communication, 2010). The two other LLWBCs' sources convey lighter waters, particularly the Solomon Strait source, with a maximum of transport at $\sigma_{\theta}=25.7 \mathrm{~kg} \mathrm{~m}^{-3}$ whereas the transport distribution within the Mindanao Current source is maximum at $\sigma_{\theta}=26.3 \mathrm{~kg}$ $\mathrm{m}^{-3}$ (Figure 8a, orange and yellow histograms, respectively). Within the interior sections, the transport is uniformly distributed in the density range of $23.1-25.7 \mathrm{~kg} \mathrm{~m}^{-3}$ (Figure 8b, green and blue histograms).

[47] The most striking feature in the comparison of the initial (at the origin sections) and final (at $165^{\circ} \mathrm{E}$ and $140^{\circ} \mathrm{W}$ ) transport distributions of the EUC sources is an important lightening of the very dense waters originating from Vitiaz Strait. The waters initially between 26.5 and $27.0 \mathrm{~kg} \mathrm{~m}^{-3}$ in Vitiaz Strait are modified so they can feed the EUC at $165^{\circ} \mathrm{E}$ in its density range, with a maximum of transport shifted to $\sigma_{\theta}=26.2 \mathrm{~kg} \mathrm{~m}^{-3}$ (Figure 8a, red histogram compared to red curve). Mindanao Current waters also lighten, although less significantly. Contrastingly, Solomon Strait waters become slightly denser during their transit to $165^{\circ} \mathrm{E}$. These results suggest that in the model, the EUC is fed by thermocline waters that are denser in Vitiaz Strait (and to a lesser extent in Mindanao Current) than the EUC waters. This may have important implications for geochemistry, and will be discussed in section 5 .

[48] The densities of the interior oceanic sources are also modified between their origin and the EUC at $140^{\circ} \mathrm{W}$. Their transport distribution is more confined within the EUC (curves in Figure 8b), meaning that relative density modifications also occur along their pathways.

[49] The simulated density modifications affecting sources of the EUC suggest that an important diapycnal mixing occurs along their pathways, particularly between Vitiaz Strait and the EUC. Rodgers et al. [2003], in a similar numerical approach, showed a much more important diapycnal mixing of the EUC sources between their subduction sites and $10^{\circ}$ latitude than the mixing experienced between the LLWBCs and the EUC. Nevertheless, our results show that even along a short pathway, within a small latitude range, diapycnal mixing is important. Understanding the location, intensity and processes yielding this mixing is a key issue but beyond the scope of this study. As a first step toward such understanding, the time mean vertical eddy diffusivity $(\mathrm{Kz})$ is plotted along selected density surfaces in Figure 9, in logarithmic scale because $\mathrm{Kz}$ spans a broad range of values. Although this diagnostic is imperfect, since $\mathrm{Kz}$ is highly variable in time, it helps to qualitatively identify and locate favorable mixing areas. Whatever the considered isopycnal surface, the western boundaries are clearly areas of important vertical mixing. More precisely, high vertical turbulence is seen in the Vitiaz Strait, along the PNG, 


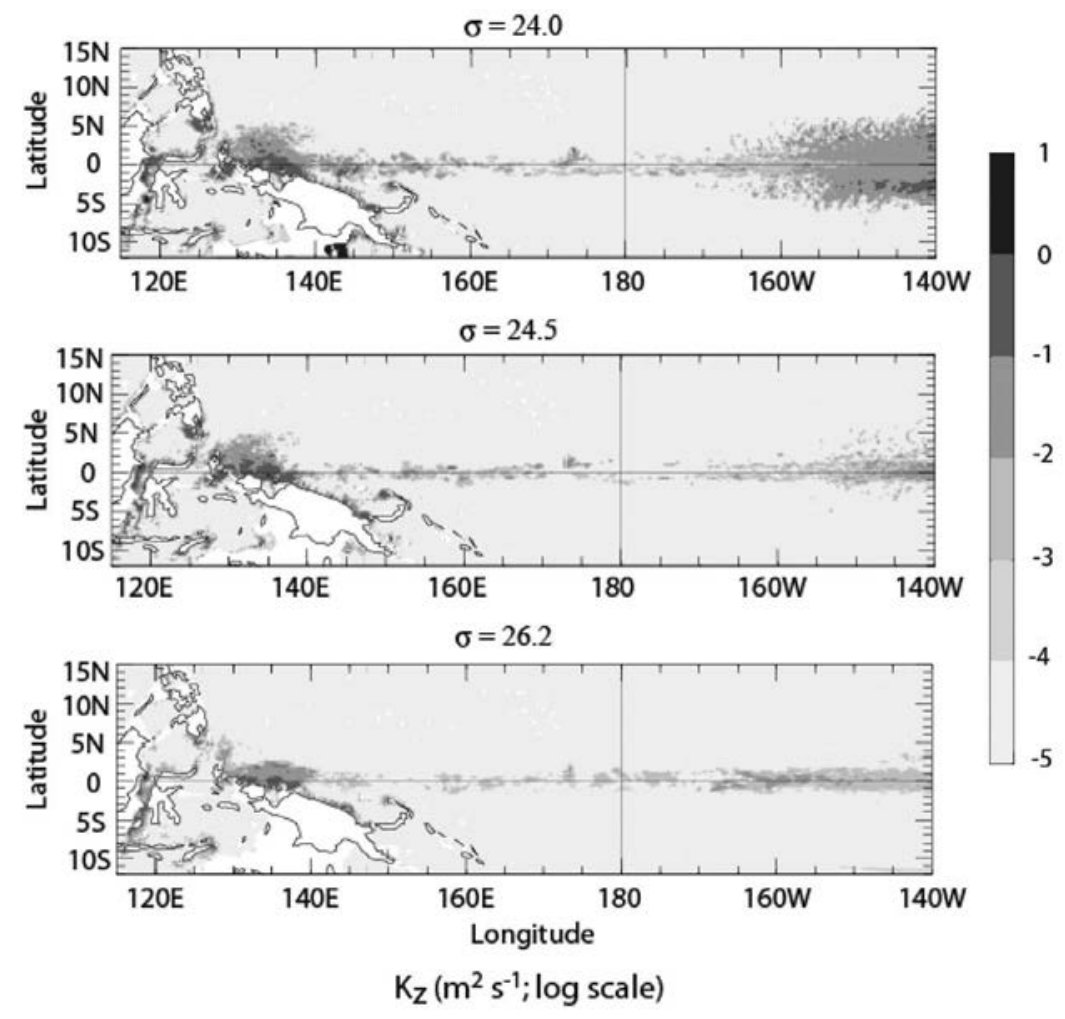

Figure 9. Time mean vertical eddy diffusion mapped with a logarithmic scale along (top) $\sigma_{\theta}=$ $24.0 \mathrm{~kg} \mathrm{~m}^{-3}$, (middle) $\sigma_{\theta}=24.5 \mathrm{~kg} \mathrm{~m}^{-3}$, and (bottom) $\sigma_{\theta}=26.2 \mathrm{~kg} \mathrm{~m}^{-3}$. The $24.0 \mathrm{~kg} \mathrm{~m}^{-3}$ isopycnal surface corresponds to the upper layer core of interior oceanic sources. The 24.5 and $26.2 \mathrm{~kg} \mathrm{~m}^{-3}$ isopycnal surfaces illustrate the initial upper and lower layer cores of the LLWBCs' sources, respectively, and correspond to the central and lower thermocline.

Mindanao and Celebes coasts, north of New Ireland, within the Halmahera Eddy and within the New Guinea Eddy (NGE). Between $150^{\circ} \mathrm{E}$ to $165^{\circ} \mathrm{W}, \mathrm{Kz}$ is weak along the equator and insignificant elsewhere (Figure 9). East of $165^{\circ} \mathrm{W}$, along the equator, mixing is important, owing to vertical current shear. Along the $24.0 \mathrm{~kg} \mathrm{~m}^{-3}$ isopycnal surface, between $5^{\circ} \mathrm{S}$ and $6^{\circ} \mathrm{N}$, it strengthens significantly (Figure 9, top). This indicates that EUC waters undergo continuously mixing along their pathway to the eastern Pacific.

[50] These Kz distributions are coherent with the fact that Vitiaz Strait waters are the most modified along their transit, compared to other sources. Indeed, they flow through areas of high $\mathrm{Kz}$ all along their travel from their source to $150^{\circ} \mathrm{E}$ (Figures $4 \mathrm{~b}$ and 9). However, this conclusion does not hold for the Solomon Strait waters, which follow a similar route to Vitiaz Strait waters, without flowing along the PNG coast. An ongoing detailed analysis of the present model and other simulations together with field data will help to better understand and quantify these differences. Along $\sigma_{\theta}=$ $24.0 \mathrm{~kg} \mathrm{~m}^{-3}$, the high equatorial $\mathrm{Kz}$, east of $165^{\circ} \mathrm{W}$ suggests a favorable area for the property modifications of the interior oceanic sources which is coherent with the interior source modifications observed in Figure 8.

[51] The EUC is not the sole destination of water carried by the LLWBCs. Figure 10 shows the fate of the total equatorward transport incoming at the western boundary sections. Waters from the NGCU also feed the NECC, mainly in the surface layer (not shown). About half of the waters flowing through Vitiaz Strait within the density range $26.9-27.2 \mathrm{~kg} \mathrm{~m}^{-3}$ join the equatorial intermediate waters, and $30 \%$ feed the Indonesian Throughflow. Only a negligible fraction flows northward below the MC. This result conflicts with Qu and Lindstrom's [2004] paper that shows a northward intrusion of intermediate waters to $15^{\circ} \mathrm{N}$, but it agrees with the observational and numerical results of Zenk et al. [2005]. Indeed, the later authors observed two fates for the Antarctic Intermediate Water (AAIW): the eastward Southern and Northern Intermediate Countercurrents (SICC and NICC) centered on $2^{\circ} \mathrm{S}$ and $2^{\circ} \mathrm{N}$, respectively, and the deep throughflow into the Celebes Sea.

[52] The destination of the Solomon Strait outflow is almost entirely the EUC in the density range $23.0-26.0 \mathrm{~kg}$ $\mathrm{m}^{-3}$ (Figure 10b). At higher densities, most of the flow recirculates within the strait, and a peak transport centered on $27.2 \mathrm{~kg} \mathrm{~m}^{-3}$, corresponding to the AAIW, reaches the equatorial intermediate current system.

[53] Finally, the smallest equatorial Pacific supply comes from the Mindanao Current (Figure 10c). Indeed, almost half of the total flow, initially distributed between $\sigma_{\theta}=$ $21.1 \mathrm{~kg} \mathrm{~m}^{-3}$ and $\sigma_{\theta}=27.2 \mathrm{~kg} \mathrm{~m}^{-3}$, feeds the Indonesian throughflow. An important southward flow centered on $\sigma_{\theta}=27.8 \mathrm{~kg} \mathrm{~m}^{-3}$ recirculates or feeds the equatorial and northern interior sections. This transport corresponds to 

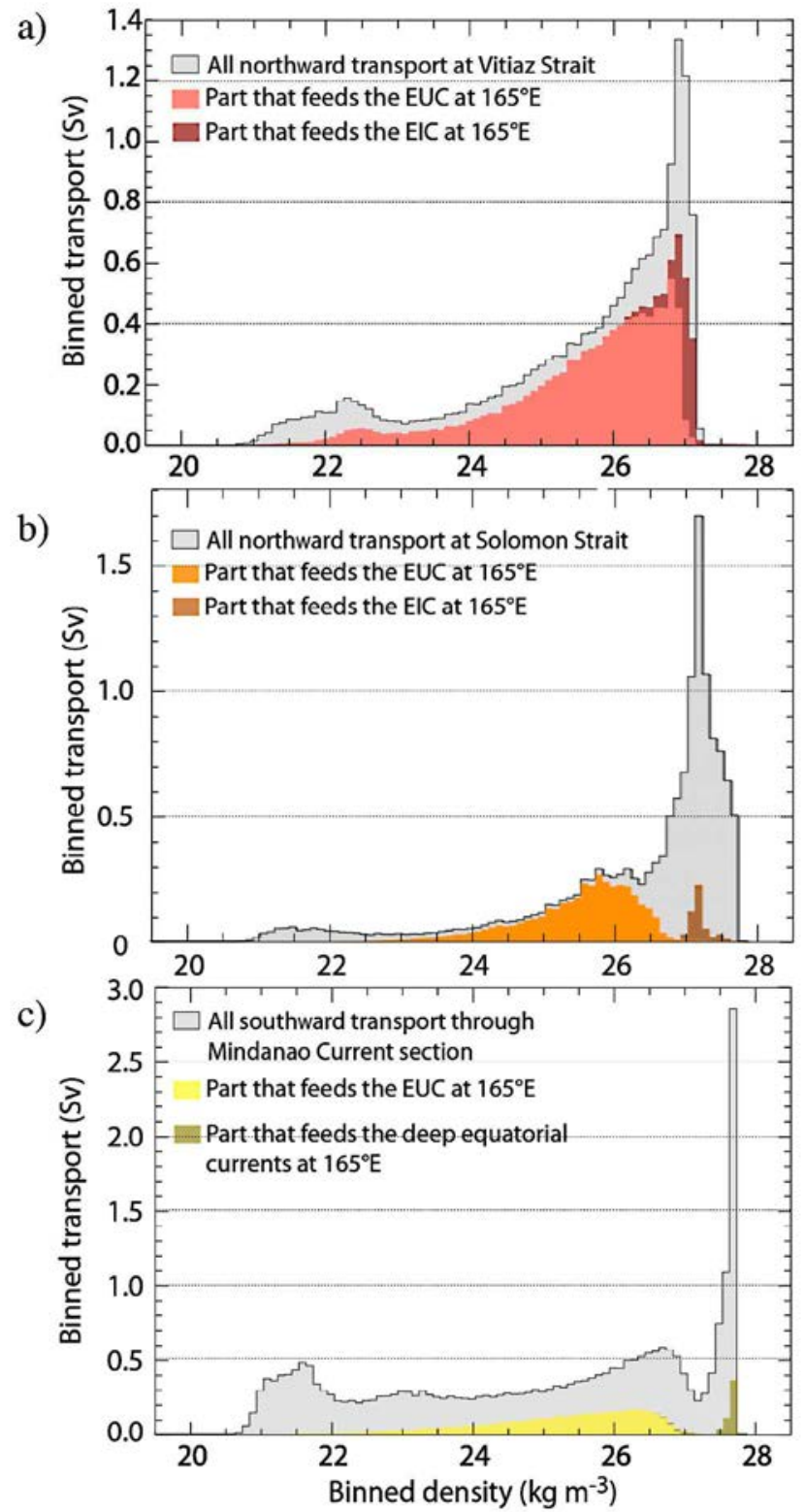

Figure 10. Transport distribution as a function of density of the equatorward inflow through the three LLWBC sections: (a) Vitiaz Strait, (b) Solomon Strait, and (c) along Mindanao coast. The full inflow is shown in the gray background, whereas the fraction that eventually reaches the $2.625^{\circ} \mathrm{S}-2.625^{\circ} \mathrm{N}$ section at $165^{\circ} \mathrm{E}$ is shown in the foreground, with bright colors when it is conveyed by the EUC and with dark colors when it is conveyed by other equatorial currents (SEC, EIC, or deeper currents). Here, the Lagrangian particles are injected only during 10 years, from 1971 to 1980 , to allow a temporal integration 10 years longer than that for the backward experiment and thus to intercept slower deep currents. deep waters; the spin-up of the model is however too short ( 8 years, from 1950 to 1957) compared with the advective time scales of these waters to allow us to draw conclusions on these water masses.

\section{Conclusions and Discussion}

[54] This study investigated the supply of water to the EUC from the Low-Latitude Western Boundary Currents of the western Pacific. In this area, defined as a water mass crossroads by Fine et al. [1994], converging northern and southern hemisphere waters meet in the vicinity of the equator and mix together. Thus, their contribution to the EUC transport and their properties evolve along their pathways to the EUC. Since the EUC is the main source of waters for the equatorial upwelling, improving our knowledge about its sources is crucial.

[55] We used a Lagrangian framework applied to a $1 / 4^{\circ}$ resolution OGCM to quantify the transports, pathways and density evolution of the waters that form the EUC from $156^{\circ} \mathrm{E}$ to $140^{\circ} \mathrm{W}$. Our model results mostly confirm the pathways deduced from previous observational studies [Tsuchiya et al., 1989; Fine et al., 1994; Kashino et al., 1996]. Yet, the modeled analysis used in this study allowed a more detailed and quantified description of these pathways. We notably found that the EUC waters at $156^{\circ} \mathrm{E}$ mainly come from the South Pacific LLWBCs, with $40 \%$ of the EUC transport due to waters originating from the NGCU at Vitiaz Strait and 28\% from the NICU east of New Ireland. The North Pacific LLWBC, the Mindanao Current, also significantly feeds up to $18 \%$ of the transport of the EUC. Most of these MC waters circulate into the Celebes Sea, and/ or around the Halmahera Eddy before joining the equatorial band. Our results suggest that the contribution of the LLWBCs to the EUC is higher than formerly thought: west of the dateline, they supply almost the entire EUC transport.

[56] This study brings new information about the distribution of sources within the EUC. In our model, waters conveyed by the NGCU from Vitiaz Strait are the major contributors to the EUC transport and feed its central and lower parts on both sides of the equator. Waters conveyed by the Mindanao Current and by the NICU remain within the northern $\left(0^{\circ}-2^{\circ} \mathrm{N}\right)$ and southern $\left(2^{\circ} \mathrm{S}-1^{\circ} \mathrm{N}\right)$ portions of the EUC, respectively. The Interior Ocean ventilates the upper part of the EUC in each hemisphere while the lowest part of the EUC is fed by recirculation from the equatorial intermediate waters.

[57] Interestingly, our model also suggests that the EUC is fed by waters flowing through Vitiaz Strait and along the PNG coasts at higher densities than those of the EUC (down to $\sigma_{\theta}=27.2 \mathrm{~kg} \mathrm{~m}^{-3}$ ). These waters undergo an important density modification between Vitiaz Strait and the EUC at $165^{\circ} \mathrm{E}$ with notably a substantial lightening of dense waters that eventually enter the equatorial band within the range of EUC densities.

[58] Waters flowing equatorward in the $\mathrm{MC}$ and $\mathrm{NICU}$ that are incorporated into the EUC have lower densities than Vitiaz Strait water masses. As a consequence, the waters originating from other sources than the NGCU (MC, Solomon Strait and interior pathways) are less modified in density, but also undergo mixing. Some strong vertical eddy diffusivity exists in many areas of the western equatorial 
Pacific. Eastern coasts of New Guinea, New Guinea and Halmahera Eddies, New Ireland and Mindanao islands appear to be areas of increased turbulence for the upper, central and lower thermocline. In the upper thermocline, vertical mixing also occurs east of $165^{\circ} \mathrm{W}$ along the equator within the EUC. Thus, all pathways followed by the waters feeding the EUC are subject to mixing. The detailed location, intensity, and processes yielding this mixing will be detailed in a further work, as well as the temperature and salinity modifications of the LLWBCs' waters.

[59] The Lagrangian software coupled to the OGCM is a powerful tool, and provided important new results about the EUC sources pathways, properties and evolutions. However, the results are reliant on the model performance. The OGCM, validated against observations, showed good skill in simulating the mean currents and densities, but also some weaknesses. The validity of our results is now discussed in the light of the model drawbacks.

[60] First, the model $1 / 4^{\circ}$ zonal resolution is not sufficient to resolve all the complex topography of the small islands and straits in the southwestern tropical Pacific. For instance, the St. George's Channel is closed in our model, whereas Melet et al. [2011] estimated its outflow to a significant transport of $2.5 \mathrm{~Sv}$ in the thermocline. The evolution of water masses exiting the Solomon Sea through St. George's Channel may be different from the evolution of those flowing through Solomon Strait, because the former may not undergo as strong turbulent mixing as the one diagnosed along the New Ireland coast. Our $1 / 4^{\circ}$ resolution model is not fully eddy resolving and an analysis of horizontal resolution impacts is beyond the scope of this study. However, we compared our results with those given by a $1 / 8^{\circ}$ resolution ROMS simulation, where the St. George's Channel is open, and found similar transports, in average different by $5 \%$. Consequently, this comparison made us confident in the robustness of our results. Nevertheless, an interesting perspective to this work is to investigate whether our conclusions change when using a model with higher resolution and/or different numerical settings.

[61] Both the modeled NGCU along PNG and the EUC at $147^{\circ} \mathrm{E}$ are shallower and stronger than observed. However, the depth of the EUC core at $156^{\circ} \mathrm{E}$ and downstream is correctly simulated. It is possible that, in reality, the NGCU waters flowing at higher densities than modeled exit the EUC between $147^{\circ} \mathrm{E}$ and $156^{\circ} \mathrm{E}$. The fraction of NICU waters (flowing at lower densities than the NGCU waters) that directly retroflects and join the EUC between $147^{\circ} \mathrm{E}$ and $156^{\circ} \mathrm{E}$, without rejoining the NGCU along the PNG coast, may also be more important than the one found in the model. Thus, along the PNG coast, and west of $156^{\circ} \mathrm{E}$, the real NGCU and EUC should be weaker and deeper than modeled, but the observed EUC should be similar to the modeled EUC east of $156^{\circ} \mathrm{E}$. This is exactly what is shown in Figure 3. Thus, the exact pathways of the NICU branch are subject to uncertainty. However, our conclusions about the transports at $156^{\circ} \mathrm{E}$ and eastward should not be affected. Nevertheless, this study highlights temporal and spatial undersampling of this critical region. The transport variability of the two branches downstream the NICU bifurcation, north of New Ireland, would especially be worth sampling.
[62] Another limitation of our model is the misrepresentation of the Subsurface Countercurrents (SCCs). The southern SCC origin is located close to Solomon Strait and flows at densities close to $26.5-26.75 \mathrm{~kg} \mathrm{~m}^{-3}$ [Rowe et al., 2000]. Some of the waters of the NGCU and NICU flowing at these densities may feed this SCC instead of the EUC, and our model may overestimate the contribution of these sources to the EUC. The same is true for the Mindanao Current and the northern SCC.

[63] Mackey et al. [2002], Lacan and Jeandel [2001], and Slemons et al. [2010, also submitted manuscript, 2011] highlighted the western Pacific and the NGCU as being a major source of iron for the EUC waters. Iron is considered the main limiting nutrient for phytoplankton growth in the eastern equatorial Pacific, which explains its HNLC nature [Martin et al., 1994]. Our results fully support the fact that the NGCU is a major route for EUC waters. In addition, Slemons et al. [2010] found maximum iron concentrations to be located in the deepest part at $165^{\circ} \mathrm{E}$, at $\sim 250 \mathrm{~m}$ (and downstream) at densities of $26.4 \mathrm{~kg} \mathrm{~m}^{-3}$ while the same maximum was found deepest in the NGCU $(460 \mathrm{~m}, 26.9 \mathrm{~kg}$ $\mathrm{m}^{-3}$ ) [see Slemons et al., 2010, Figures 5 and 6]. Such depth difference was a somewhat puzzling result as it was not clear how to relate the two water masses. Our findings give a rationale for Slemons et al.'s [2010] results where iron rich waters from the NGCU at such low densities can eventually feed the lowest EUC part, lightening along their route to the EUC under the influence of mixing. However, our study does not provide information about the SCCs capacity to convey enriched waters toward the eastern Pacific, because of their misrepresentation in the model. Whether or not these powerful eastward veins play an important role as micronutrient conveyers remains to be elucidated.

[64] Finally, the Lagrangian calculations are made here over 20 years and therefore simulate pathways integrated in time. However, the pathways vary depending on the season and on the El Niño-Southern Oscillation phase [Ryan et al., 2006; Gorgues et al., 2010]. Ridgway et al. [1993] and Melet et al. [2010b] demonstrated that the transports in Vitiaz and Solomon Straits increase during an El Niño event. What is the fate of this excess water transport? Do these sources differently feed the EUC, which strongly weakens during an El Niño event? This should be explored in future studies.

[65] Acknowledgments. We would like to thank Gregory C. Johnson, Iawo Ueki, and the TAO project office for making their data available to us (TAO data are available online at http://www.pmel.noaa.gov). We also want to thank the DRAKKAR project for making the ORCA025-G70 simulation available. We acknowledge the use of the ARIANE Lagrangian tool (http:// www.univ-brest.fr/lpo/ariane/). Support for this study has been provided by the Centre National de Recherche Scientifique (CNRS/INSU, LEFE program), the Agence Nationale de la Recherche (ANR), and the Institut de Recherche pour le Développement (IRD). Finally, we would like to thank James W. Murray and the anonymous reviewer for their valuable comments and suggestions, which improved the quality of this paper.

\section{References}

Arakawa, A. (1972), Design of the UCLA general circulation model: Numerical simulation of weather and climate, Tech. Rep. 7, 116 pp., Dep. of Meteorol., Univ. of Calif., Los Angeles.

Barnier, B., et al. (2006), Impact of partial steps and momentum advection schemes in a global ocean circulation model at eddy-permitting resolution, Ocean Dyn., 56, 543-567, doi:10.1007/s10236-006-0082-1.

Blanke, B., and P. Delecluse (1993), Variability of the tropical Atlantic Ocean simulated by a general circulation model with two different 
mixed-layer physics, J. Phys. Oceanogr., 23, 1363-1388, doi:10.1175/ 1520-0485(1993)023<1363:VOTTAO $>2.0 . \mathrm{CO} ; 2$

Blanke, B., and S. Raynaud (1997), Kinematics of the Pacific Equatorial Undercurrent: An Eulerian and Lagrangian approach from GCM results, J. Phys. Oceanogr., 27, 1038-1053, doi:10.1175/1520-0485(1997) 027<1038:KOTPEU>2.0.CO;2.

Blanke, B., M. Arhan, G. Madec, and S. Roche (1999), Warm water paths in the equatorial Atlantic as diagnosed with a general circulation model, J. Phys. Oceanogr., 29, 2753-2768, doi:10.1175/1520-0485(1999) 029<2753:WWPITE $>2.0 . \mathrm{CO} ; 2$.

Butt, J., and E. Lindstrom (1994), Currents off the east coast of New Ireland, Papua New Guinea, and their relevance to regional undercurrents in the western equatorial Pacific Ocean, J. Geophys. Res., 99 12,503-12,514, doi:10.1029/94JC00399.

Chavez, F. P., and R. T. Barber (1987), An estimate of new production in the equatorial Pacific, Deep Sea Res., Part A, 34, 1229-1243, doi:10.1016/0198-0149(87)90073-2.

Chavez, F. P., and J. R. Toggweiler (1995), Physical estimates of global new production: The upwelling contribution, in Upwelling in the Ocean: Modern Processes and Ancient Records, edited by C. P. Summerhayes, pp. 313-320, John Wiley, New York.

Cravatte, S., A. Ganachaud, Q.-P. Duong, W. S. Kessler, G. Eldin, and P. Dutrieux (2011), Observed circulation in the Solomon Sea from SADCP data, Prog. Oceanogr., 88, 116-130, doi:10.1016/j.pocean. 2010.12.015.

Dutrieux, P., et al. (2008), Thermocline and subthermocline currents from the central to western equatorial Pacific: A snapshot view from the EUC-Fe campaign, paper presented at the 2008 Ocean Sciences Meeting, Am. Soc. of Limnol. and Oceanogr., Orlando, Fla., 2-7 March.

Fine, R. A., R. Lukas, F. Bingham, M. J. Warnar, and R. H. Gammon (1994), The western equatorial Pacific: A water mass crossroads, J. Geophys. Res., 99, 25,063-25,080, doi:10.1029/94JC02277.

Fukumori, I., T. Lee, B. Cheng, and D. Menemenlis (2004), The origin, pathway, and destination of Niño-3 water estimated by a simulated passive tracer and its adjoint, J. Phys. Oceanogr., 34, 582-604, doi:10.1175/ 2515.1.

Goodman, P. J., W. Hazeleger, P. de Vries, and M. Cane (2005), Pathways into the Pacific Equatorial Undercurrent: A trajectory analysis, J. Phys. Oceanogr., 35, 2134-2151, doi:10.1175/JPO2825.1.

Gordon, A. L., and R. A. Fine (1996), Pathways of water between the Pacific and Indian oceans in the Indonesian seas, Nature, 379 , 146-149, doi:10.1038/379146a0.

Gordon, R. M., K. H. Coale, and K. S. Johnson (1997), Iron distributions in the equatorial Pacific: Implications for new production, Limnol. Oceanogr., 42, 419-431, doi:10.4319/lo.1997.42.3.0419.

Gorgues, T., C. Menkes, Y. Dandonneau, S. Alvain, C. Moulin, L. Slemons, and M.-H. Radenac (2010), Revisiting the La Niña 1998 phytoplankton blooms in the equatorial Pacific, Deep Sea Res., Part I, 57, 567-576, doi:10.1016/j.dsr.2009.12.008.

Gouriou, Y., and J. Toole (1993), Mean circulation of the upper layers of the western equatorial Pacific ocean, J. Geophys. Res., 98, 22,495-22,520, doi:10.1029/93JC02513.

Hautala, S. L., J. S. Reid, and N. Bray (1996), The distribution and mixing of Pacific water masses in the Indonesian Seas, J. Geophys. Res., 101 12,353-12,373, doi:10.1029/96JC00037.

Hayes, S. P., L. J. Mangum, J. Picaut, A. Sumi, and K. Takeuchi (1991), TOGATAO: A moored array for real-time measurements in the tropical Pacific Ocean, Bull. Am. Meteorol. Soc., 72, 339-347, doi:10.1175/ 1520-0477(1991)072<0339:TTAMAF $>2.0 . \mathrm{CO} ; 2$.

Izumo, T., J. Picaut, and B. Blanke (2002), Tropical pathways, equatorial undercurrent variability and the 1998 La Niña, Geophys. Res. Lett., 29(22), 2080, doi:10.1029/2002GL015073.

Johnson, G. C., and M. J. McPhaden (1999), Interior pycnocline flow from the subtropical to the equatorial Pacific Ocean, J. Phys. Oceanogr., 29 3073-3089, doi:10.1175/1520-0485(1999)029<3073:IPFFTS $>2.0$. CO;2.

Johnson, G. C., B. M. Sloyan, W. S. Kessler, and K. E. McTaggart (2002), Direct measurements of upper ocean currents and water properties across the tropical Pacific during the 1990s, Prog. Oceanogr., 52, 31-61, doi:10.1016/S0079-6611(02)00021-6.

Kashino, Y., M. Aoyama, T. Kawano, N. Hendiarti, Syaefudin, Y. Anantasena, K. Muneyama, and H. Watanabe (1996), The water masses between Mindanao and New Guinea, J. Geophys. Res., 101, 12,391-12,400, doi:10.1029/95JC03797.

Kashino, Y., I. Ueki, Y. Kuroda, and A. Purwandani (2007), Ocean variability north of New Guinea derived from TRITON buoy data, J. Oceanogr., 63, 545-559, doi:10.1007/s10872-007-0049-y.

Lacan, F., and C. Jeandel (2001), Tracing Papua New Guinea imprint on the central equatorial Pacific Ocean using neodymium isotopic compositions and Rare Earth Element patterns, Earth Planet. Sci. Lett., 186, 497-512, doi:10.1016/S0012-821X(01)00263-1.

Landry, M. R., et al. (1997), Iron and grazing constraints on primary production in the central equatorial Pacific: An EqPac synthesis, Limnol. Oceanogr., 42, 405-418, doi:10.4319/1o.1997.42.3.0405.

Large, W., and S. Yeager (2004), Diurnal to decadal global forcing for ocean and sea-ice models: The datasets and flux climatologies, Tech. Note NCAR/TN-460+STR, Natl. Cent. for Atmos. Res., Boulder, Colo.

Levitus, S., et al. (1998), World Ocean Database 1998, vol. 1, Introduction, NOAA Atlas NESDIS 18, 346 pp., U.S. Dep. of Commer., Washington, D.C

Lindstrom, E., R. Lukas, R. Fine, E. Firing, S. Godgrey, G. Meyers, and M. Tsuchiya (1987), The western equatorial ocean circulation study, Nature, 330, 533-537, doi:10.1038/330533a0.

Liu, Z., S. G. H. Philander, and R. C. Pacanowski (1994), A GCM study of tropical-subtropical upper-ocean water exchange, J. Phys. Oceanogr., 24, 2606-2623, doi:10.1175/1520-0485(1994)024<2606:AGSOTU>2.0. $\mathrm{CO} ; 2$.

Lu, P., and J. P. McCreary (1995), Influence of the ITCZ on the flow of thermocline water from the subtropical to the equatorial Pacific Ocean, J. Phys. Oceanogr., 25, 3076-3088, doi:10.1175/1520-0485(1995) 025<3076:IOTIOT $>2.0 . \mathrm{CO} ; 2$

Lukas, R., T. Yamagata, and J. P. McCreary (1996), Pacific low-latitude western boundary currents and the Indonesian throughflow, J. Geophys. Res., 101, 12,209-12,216, doi:10.1029/96JC01204.

Mackey, D. J., J. E. O’Sullivan, and R. J. Watson (2002), Iron in the western Pacific: A riverine or hydrothermal source for iron in the Equatorial Undercurrent, Deep Sea Res., Part I, 49, 877-893, doi:10.1016/S09670637(01)00075-9.

Marin, F., B. L. Hua, and S. Wacongne (2000), The equatorial thermostad and subsurface countercurrents in the light of atmospheric Hadley cells mechanism, J. Mar. Res., 58, 405-437, doi:10.1357/ 002224000321511098

Marin, F., E. Kestenare, T. Delcroix, F. Durand, S. Cravatte, G. Eldin, and R. Bourdallé-Badie (2010), Annual reversal of the Equatorial Intermediate Current in the Pacific: Observations and model diagnostics, J. Phys. Oceanogr., 40, 915-933, doi:10.1175/2009JPO4318.1.

Martin, J. H., et al. (1994), Testing the iron hypothesis in ecosystems of equatorial Pacific Ocean, Nature, 371, 123-129, doi:10.1038/371123a0.

McPhaden, M. J. (1988), PMEL current mooring program in the tropical Pacific, in Proceedings of the U.S. Global Ocean Flux Study Pacific Planning Report, JGOFS Plann. Rep. 9, pp. 91-94, Woods Hole Oceanogr. Inst., Woods Hole, Mass.

Melet, A., L. Gourdeau, W. S. Kessler, J. Verron, and J.-M. Molines (2010a), Thermocline circulation in the Solomon Sea: A modeling study, J. Phys. Oceanogr., 40, 1302-1319, doi:10.1175/2009JPO4264.1.

Melet, A., L. Gourdeau, and J. Verron (2010b), Variability in Solomon Sea circulation derived from altimeter sea level data, Ocean Dyn., 60 883-900, doi:10.1007/s10236-010-0302-6.

Melet, A., J. Verron, L. Gourdeau, and A. Koch-Larrouy (2011), Equatorward pathways of Solomon Sea water masses and their modifications, J. Phys. Oceanogr. 41, 810-826, doi:10.1175/2010JPO4559.1.

Molines, J.-M., B. Barnier, T. Penduff, L. Brodeau, A.-M. Treguier, S. Theetten, and G. Madec (2006), Definition of the interannual experiment ORCA025-G70, 1958-2004, Rep. LEGI-DRA-2-11-2006i, Lab. des Ecoulements Geophys. et Ind., Grenoble, France.

Murray, J. W., R. T. Barber, M. R. Roman, M. P. Bacon, and R. A. Feely (1994), Physical and biological controls on carbon cycling in the equatorial Pacific, Science, 266, 58-65, doi:10.1126/science.266.5182.58.

Qu, T., and E. J. Lindstrom (2004), Northward intrusion of Antarctic Intermediate Water in the western Pacific, J. Phys. Oceanogr., 34, 2104-2118, doi:10.1175/1520-0485(2004)034<2104:NIOAIW>2.0.CO;2.

Ridgway, K. R., J. S. Godfrey, G. Meyers, and R. Bailey (1993), Sea level response to the 1986-1987 El-Nino Southern Oscillation event in the western Pacific in the vicinity of Papua New Guinea, J. Geophys. Res. 98, 16,387-16,395, doi:10.1029/93JC00766.

Rodgers, K. B., B. Blanke, G. Madec, O. Aumont, P. Ciais, and J.-C. Dutay (2003), Extratropical sources of equatorial Pacific upwelling in an OGCM, Geophys. Res. Lett., 30(2), 1084, doi:10.1029/2002GL016003.

Rowe, G. D., E. Firing, and G. C. Johnson (2000), Pacific equatorial subsurface countercurrent velocity, transport, and potential vorticity, J. Phys. Oceanogr., 30, 1172-1187, doi:10.1175/1520-0485(2000) 030<1172:PESCVT>2.0.CO;2.

Ryan, J. P., I. Ueki, Y. Chao, H. Hang, P. S. Polito, and F. P. Chavez (2006), Western Pacific modulation of large phytoplankton blooms in the central and eastern equatorial Pacific, J. Geophys. Res., 111, G02013, doi:10.1029/2005JG000084

Schiller, A., P. R. Oke, G. B. Brassington, M. Entel, R. Fiedler, D. A. Griffin, and J. V. Mansbridge (2008), Eddy-resolving ocean circulation 
in the Asian-Australian region inferred from an ocean reanalysis effort, Prog. Oceanogr., 76, 334-365, doi:10.1016/j.pocean.2008.01.003.

Schneider, N. (2004), The response of tropical climate to the equatorial emergence of spiciness anomalies, J. Clim., 17, 1083-1095, doi:10.1175/ 1520-0442(2004)017<1083:TROTCT $>2.0$. CO;2.

Schott, F. A., J. P. McCreary, and G. C. Johnson (2004), Shallow overturning circulations of the tropical-subtropical oceans, in Earth Climate: The Ocean-Atmosphere Interaction, Geophys. Monogr. Ser., vol. 147, edited by C. Wang et al., pp. 261-304, AGU, Washington, D. C.

Slemons, L. O., J. W. Murray, T. Gorgues, O. Aumont, and C. Menkes (2009), Biogeochemical impact of a model western iron source in the Pacific Equatorial Undercurrent, Deep Sea Res., Part I, 56, 2115-2128, doi:10.1016/j.dsr.2009.08.005.

Slemons, L. O., J. W. Murray, B. Paul, and P. Dutrieux (2010), Western Pacific coastal sources of iron, manganese and aluminum to the Equatorial Undercurrent, Global Biogeochem. Cycles, 24, GB3024, doi:10.1029 2009GB003693.

Stockdale, T., A. Busalacchi, D. E. Harrison, and R. Seager (1998), Ocean modeling for ENSO, J. Geophys. Res., 103, 14,325-14,355, doi:10.1029/ 97JC02440.

Tsuchiya, M., R. Lukas, R. Fine, E. Firing, and E. Lindstrom (1989), Source waters of the Pacific Equatorial Undercurrent, Prog. Oceanogr., 23, 101-147, doi:10.1016/0079-6611(89)90012-8.

Ueki, I., Y. Kashino, and Y. Kuroda (2003), Observation of current variations off the New Guinea coast including the 1997-1998 El Niño period and their relationship with Sverdrup transport, J. Geophys. Res., 108(C7), 3243, doi:10.1029/2002JC001611.

Uppala, S. M., et al. (2005), The ERA-40 re-analysis, Q. J. R. Meteorol. Soc., 131, 2961-3012, doi:10.1256/qi.04.176.

Wijffels, S., E. Firing, and J. Toole (1995), The mean structure and variability of the Mindanao Current at $8^{\circ} \mathrm{N}, J$. Geophys. Res., 100, 18,421-18,435, doi:10.1029/95JC01347.

Zenk, W., G. Siedler, A. Ishida, J. Holfort, Y. Kashino, Y. Kuroda, T. Miyama, and T. J. Müller (2005), Pathways and variability of the Antarctic Intermediate Water in the western equatorial Pacific Ocean, Prog. Oceanogr., 67, 245-281, doi:10.1016/j.pocean.2005.05.003.

B. Blanke, Laboratoire de Physique des Océans, UMR 6523, CNRS/ IFREMER/IRD/UBO, Université de Bretagne Occidentale, UFR Sciences, 6 avenue Le Gorgeu, F-29238 Brest CEDEX, France.

S. Cravatte, F. Durand, M. Grenier, C. Jeandel, and A. Koch-Larrouy, LEGOS, 14 Avenue Edouard Belin, F-31400 Toulouse CEDEX, France. (melanie.grenier@legos.obs-mip.fr)

A. Melet, LEGI, UMR 5519, CNRS, Université de Grenoble, BP 53 F-38041 Grenoble CEDEX 9, France.

C. Menkes, LOCEAN, UPMC/IRD/CNRS/MNHN, Université Pierre et Marie Curie, Case 100, 4 place Jussieu, F-75252 Paris CEDEX 05, France. 